Review

\title{
Plant Flavonoids in Mediterranean Species: A Focus on Flavonols as Protective Metabolites under Climate Stress
}

\author{
Justine Laoué *(D), Catherine Fernandez (D) and Elena Ormeño*(D) \\ Aix Marseille University, Avignon University, CNRS, IRD, IMBE, 13003 Marseille, France; \\ catherine.fernandez@imbe.fr \\ * Correspondence: justine.laoue@gmail.com (J.L.); elena.ormeno-lafuente@imbe.fr (E.O.)
}

Citation: Laoué, J.; Fernandez, C.; Ormeño, E. Plant Flavonoids in Mediterranean Species: A Focus on Flavonols as Protective Metabolites under Climate Stress. Plants 2022, 11, 172. https://doi.org/10.3390/ plants11020172

Academic Editor: Beatriz Ramos Solano

Received: 10 December 2021

Accepted: 5 January 2022

Published: 10 January 2022

Publisher's Note: MDPI stays neutral with regard to jurisdictional claims in published maps and institutional affiliations.

Copyright: (C) 2022 by the authors. Licensee MDPI, Basel, Switzerland. This article is an open access article distributed under the terms and conditions of the Creative Commons Attribution (CC BY) license (https:// creativecommons.org/licenses/by/ $4.0 /)$.

\begin{abstract}
Flavonoids are specialized metabolites largely widespread in plants where they play numerous roles including defense and signaling under stress conditions. These compounds encompass several chemical subgroups such as flavonols which are one the most represented classes. The most studied flavonols are kaempferol, quercetin and myricetin to which research attributes antioxidative properties and a potential role in UV-defense through UV-screening mechanisms making them critical for plant adaptation to climate change. Despite the great interest in flavonol functions in the last decades, some functional aspects remain under debate. This review summarizes the importance of flavonoids in plant defense against climate stressors and as signal molecules with a focus on flavonols in Mediterranean plant species. The review emphasizes the relationship between flavonol location (at the organ, tissue and cellular scales) and their function as defense metabolites against climate-related stresses. It also provides evidence that biosynthesis of flavonols, or flavonoids as a whole, could be a crucial process allowing plants to adapt to climate change, especially in the Mediterranean area which is considered as one of the most sensitive regions to climate change over the globe.
\end{abstract}

Keywords: biological function; secondary metabolism; biosynthesis; localization; stress response; defense mechanism; antioxidant; leaves; reactive oxygen species

\section{Introduction}

Plants possess thousands of plant secondary or specialized metabolites (PSMs) whose chemical diversity is species-specific. These chemicals play crucial ecophysiological roles as they are implicated in plant interactions with its environment and plant defense against environmental stress conditions [1]. Most of them can be classified within five chemical families: terpenes, phenolic compounds, benzenoids, fatty acid derivatives and alkaloids. Based on their chemical structure, phenolic compounds can be divided into different subgroups including simple phenolics (one phenol unit alone) and polyphenols (with more than one phenolic unit) comprising phenolic acids, flavonoids, tannins, coumarins, lignans, quinones, stilbenes, and curcuminoids [2]. Flavonoids, a major class of polyphenols, widely present in the plant kingdom, represent a large group of PSMs which are either produced constitutively or induced by environmental stresses [3].

The role of flavonoids in protection against UV and drought stress in Mediterranean endemic species has been suggested by recent studies which show a monthly variation in the polyphenol concentrations with the highest levels occurring in summer at midday when drought, temperature and UV radiations are the highest [4,5]. It is also known that geographical factors such as latitude and altitude influence the composition of defensive chemicals including phenolic compound levels [6,7]. Mediterranean species display contrasting polyphenol compositions and concentrations [8-11] which strongly respond to abiotic stresses. This suggests a key role of phenolic compounds and species-specific functions in plants living in constraining environments such as the Mediterranean region [12]. Accordingly, accumulation of flavonoid concentrations in response to drought have also 
been reported in some Mediterranean species [13-15]. In this context, it is particularly pertinent to understand the role of flavonoids in the adaptation of Mediterranean plant species to rapid climate change.

Flavonoids feature a 15-carbon atom basic skeleton, arranged in the form C6-C3-C6 and present two aromatic rings ( $\mathrm{A}$ and $\mathrm{B}$ ) linked by a unit of three carbon atoms ( $\mathrm{C}$ ring), which may or may not give rise to a third aromatic ring [16]. There are several classes of flavonoids including chalcones, aurones, flavanonols, flavones, isoflavones, flavanols, flavonols, anthocyanins, proanthocyanidins and leucoanthocyanidins. Flavonoids can occur as aglycones, glycosides, and methylated derivatives. More than 6000 different flavonoids have been identified [17] which differ in the number and position of the hydroxyl groups, and their extent of alkylation and/or glycosylation [18]. For example, the flavonols (e.g., quercetin and kaempferol), have a 3-hydroxy pyran-4-one group on the $\mathrm{C}$ ring whereas the flavanols catechins have only a 3-hydoxyl group on the C ring [19].

Flavonoids feature a broad spectrum of biological activities in plants which has been related to their chemical diversity and can be linked to their localization within leaf tissues as addressed later in this review. They participate in many cellular activities such as signalling, auxin transport and pigmentation [20-23]. One of the most highlighted functions of flavonoids is plant protection against abiotic (e.g., drought, salinity, UV radiation and heat) and biotic (e.g., insects and pathogens attack) stresses [24-26]. Most commonly, investigations have reported that flavonoids play a role in the modulation of reactive oxygen species (ROS) and possess UV-screening mechanisms $[8,27-30]$ as described later in this review. Their action as antioxidant is based on (i) their direct capacity to scavenge ROS [31], (ii) their role in inhibition of ROS formation by chelating ion of metals $[32,33]$ and (iii) their ability to activate antioxidant enzymes [19,34]. They also act as indirect plant growth regulators as explained in the last section of this review [21,35].

One of the most important flavonoid sub-groups are flavonols which include kaempferol, quercetin and myricetin, the most studied flavonols [36]. Numerous functional roles have been attributed to flavonols, especially their role as antioxidant molecules and UV-screening pigments since they have long been considered as the most effective UV-B absorbers thus conferring strong photo-protection [37]. The catechol group in the B-ring (Figure 1), as observed in the flavonol quercetin and its derivates, makes flavonols the most effective antioxidant compounds and therefore key compounds in the plant responses to changing climate. Flavonols seem particularly important in Mediterranean plant species as studies usually report a high concentration of flavonols such as quercetin under excess light and drought stress $[8,9,38]$. The higher distribution of quercetin in Mediterranean plants may explain their ability to cope with a dry climate and high solar irradiance as this flavonol is an excellent antioxidant [31].

This review resumes the chemical and physical properties, biosynthesis, storage localization, and biological functions of plant flavonoids, and relationships among these five features with a deeper focus on flavonols. We finally focus on the response and protection conferred by flavonols under climate stress in Mediterranean plants species. All these sections are described by reviewing a number of interdisciplinary studies (biochemistry, ecology and ecophysiology studies) that have used genomic, transcriptomic, metabolomic and imaging approaches. 


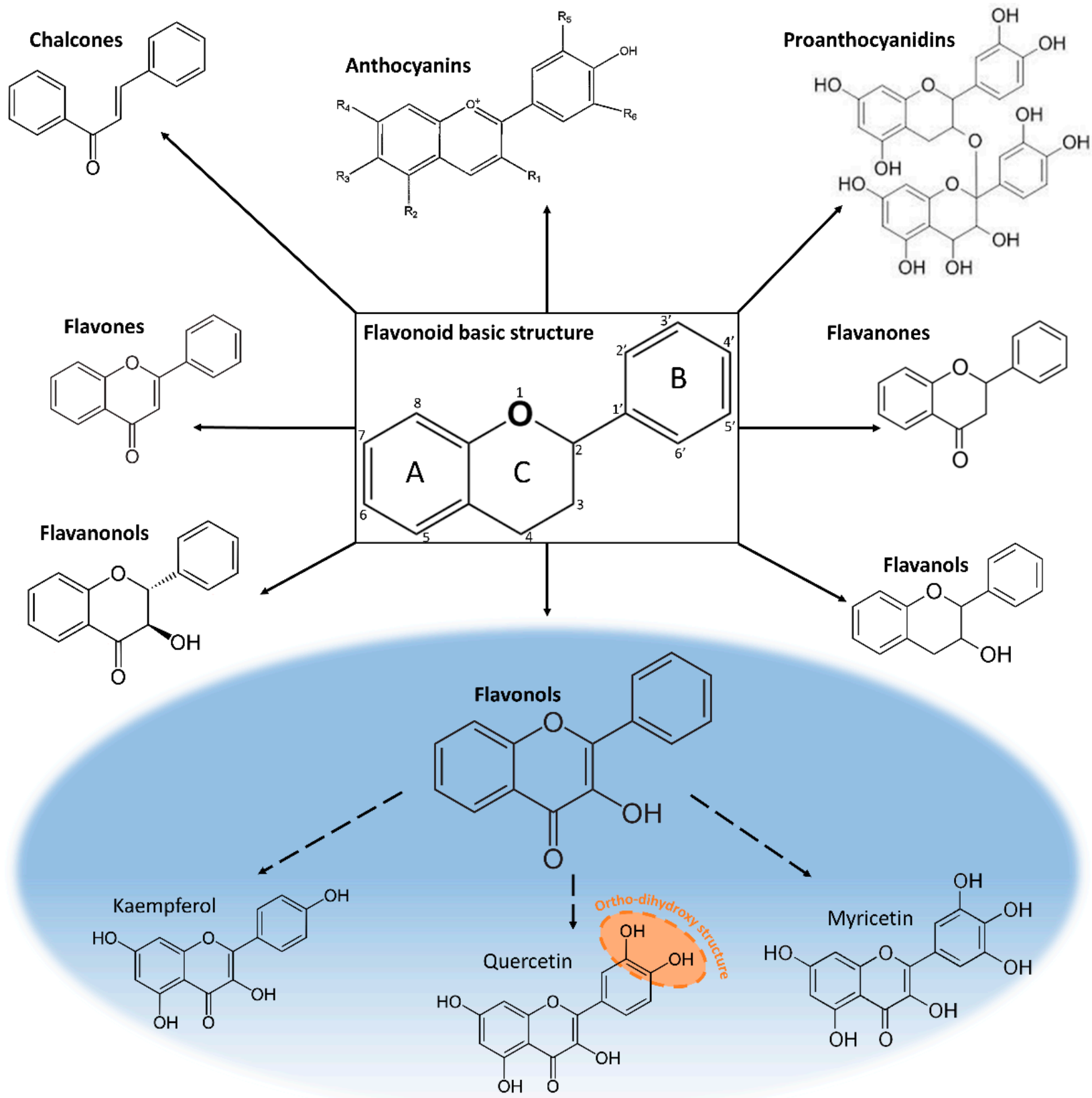

Figure 1. Structure and classification of flavonoids. The main subclasses of major flavonols are circled in blue. The difference between flavonoid groups depends on the chemical structure, the degree of oxidation, and the unsaturation of the linking chain (C3). Flavonols differ from each other in the number and position of the hydroxyl groups $(-\mathrm{OH})$. The ortho-dihydroxy structure of quercetin is circled in orange.

\section{Chemical and Physical Properties of Flavonols: Relationship with Their Function}

Flavonols, and flavonoids as a whole, have historically been studied for their functions in UV-B protection in plants because they display strong absorption in the UV spectral region and exhibit fluorescence with excitation maxima about 350-370 nm [39,40]. Their biological activity in plants remains to be elucidated and some of them are still under debate [37]. Overall, it has been proved that their functions depend on their chemical and physical properties [41].

Flavonols, closely related in structure to flavones, are characterized by the presence of a hydroxyl group $(-\mathrm{OH})$ at the $\mathrm{C} 3$ position and a carbonyl function $(\mathrm{C}=\mathrm{O})$ at the $\mathrm{C} 4$ 
position, both on the $\mathrm{C}$ ring [42] (Figure 1). In the structure of flavonoids, the $\mathrm{C}$ ring may be a heterocyclic pyran-which yields flavanols (e.g., catechin) and anthocyanidins, or pyrone-which yields flavonols (e.g., kaempferol, quercetin, myricetin), flavones (e.g., luteolin, apigenin), and flavanones (e.g., naringenin, eriodyctiol) [43] (Figure 1). Flavonol diversity is due to the aglycone structure and its oxidation or reduction state, the position of the hydroxyl group and the degree of hydroxylation [44].

Chemical structure and physical properties of flavonols are intimately linked to their biological functions. Several studies have shown that their antioxidant activity increases with the number of hydroxyl groups and depends on the - $\mathrm{OH}$ position within the molecule $[45,46]$ (Table 1). Differences in the chemical structure and the relationship to their antioxidant activities are summarized in Table 1. The substitution patterns in kaempferol, quercetin and myricetin are $3,5,7,4^{\prime}-\mathrm{OH}, 3,5,7,3^{\prime}, 4^{\prime}-\mathrm{OH}$ and $3,5,7,3^{\prime}, 4^{\prime}, 5^{\prime}-\mathrm{OH}$, respectively (Figure 1). The presence of a third-OH group in the $\mathrm{B}$ ring in myricetin does not enhance the effectiveness against aqueous phase radicals compared to quercetin [46] (Table 1), highlighting the importance of the ortho-dihydroxy structure in the B ring of quercetin which allows electron delocalization and thus increases their antioxidant activity [47] (Figure 1).

Table 1. Comparative physico-chemical properties of some of the main flavonols, flavones and flavanones. The higher the number of hydroxyl groups, the higher the antioxidant activity. An exception is made for quercetin for which the higher antioxidant activity is due to the ortho-dihydroxy structure in the B ring (see Figure 1).

\begin{tabular}{cccccc}
\hline Flavonoid Class & Compound Subclass & $\begin{array}{c}\text { Number of } \\
\text { Hydroxyl Groups }\end{array}$ & $\begin{array}{c}\text { TEAC } \\
\text { (1) }\end{array}$ & Value (mM) & $\begin{array}{c}\text { Maximum Absorption } \\
\text { Wavelength (nm) }\end{array}$ \\
\hline Flavonols & Kaempferol & 4 & $1.34 \pm 0.08$ & $1.98 \pm 0.13$ & 367 \\
\hline Flavonols & Quercetin & 5 & $4.7 \pm 0.1$ & $4.30 \pm 0.16$ & 371 \\
\hline Flavonols & Myricetin & 6 & $3.1 \pm 0.30$ & $2.45 \pm 0.35$ & 374 \\
\hline Flavones & Chrysin & 2 & $1.43 \pm 0.07$ & $0.98 \pm 0.04$ & 313 \\
\hline Flavones & Apigenin & 3 & $1.45 \pm 0.08$ & $1.04 \pm 0.06$ & 337 \\
\hline Flavanones & Naringenin & 3 & $1.53 \pm 0.05$ & $0.59 \pm 0.08$ & 289 \\
\hline Flavanonols & Taxifolin & 5 & $1.9 \pm 0.03$ & $2.43 \pm 0.12$ & 290 \\
\hline & $\begin{array}{l}\text { (1) Data extracted from Rice-Evans et al. (1996) [46]; (2) Data extracted from Melidou et al. (2005) [48]; (3) TEAC } \\
\text { (Trolox equivalent antioxidant activity) is defined as the concentration of Trolox solution with equivalent an- } \\
\text { tioxidant potential to a 1 mM concentration of the compound under investigation.; } \\
\text { wavelength Maximum absorption }\end{array}$
\end{tabular}

Similar to other PSMs, flavonols often exist in glycosylated forms (also referred to as glycoside conjugates) which are formed by an aglycone core bound to glycosidic sugars through oxygen or more rarely carbon atoms $[49,50]$. The glycosidic sugar is generally glucose, but also frequently galactose and rhamnose. The most common flavonol glycosides containing glucose are astragalin (kaempferol 3-O-glucoside) and isoquercetin (quercetin 3-O-glucoside) which have as aglycone cores kaempferol and quercetin, respectively. Myricetin can be coupled with rhamnose giving myricitrin (myricetin 3-Orhamnoside) [51,52]. Glycosylation of flavonols is of high biological importance since it tends to decrease their antioxidant activity [53-55]. For example, Rice-Evans et al. [46] have demonstrated that glycosylation of quercetin blocks the $-\mathrm{OH}$ at the $\mathrm{C} 3$ position in the $\mathrm{C}$ ring thus reducing its antioxidant capacity. Glycosylation also preserves the reactive $-\mathrm{OH}$ groups from auto-oxidation [56]. Glycoside forms of flavonols is an important structural modification which influences their physical properties by increasing their solubility, stability and bioavailability [57]. Glycosylation modifies their cellular and tissular repartition too [49] (see chapter "Biosynthesis and storage of flavonols: relationship with their function"). Overall, the functional diversity and biological activities of flavonols are due to the 
modification of the aglycone core. The attachment of functional groups such as sugars, hydroxyl and methyl groups gives flavonols their ability to have different biological roles and storage sites in the plant.

Most flavonols (as well as flavones) exhibit two major absorption bands: Band I (320$385 \mathrm{~nm}$ ) own to the B ring absorption, and Band II (250-285 nm) which refers to the A ring absorption. Increase in the numbers of hydroxyl groups in flavonoids induces an adsorption shift towards the red band such as $367 \mathrm{~nm}$ in kaempferol, $371 \mathrm{~nm}$ in quercetin and $374 \mathrm{~nm}$ in myricetin [58] (Table 1). The structure of flavanones leads to different UV absorption wavelengths (e.g., lower maximum absorption wavelength) compared to flavones and flavonols as well as a lowered antioxidant activity (Table 1). These differences can lead to various and different biological functions. In fact, dihydroxy B ring-substituted flavonoids have a greater antioxidant capacity, while their monohydroxy B ring-substituted counterparts have greater ability to absorb UV wavelengths [28].

\section{Biosynthesis and Storage of Flavonols: Relationship with Their Function}

The precursor of flavonoids is the amino acid phenylalanine which is the intermediate in the biosynthetic transformations leading from shikimic acid to phenylpropanoids [59] (Figure 2). Phenylalanine, derived from the shikimate pathway, is synthetized in chloroplasts and then transported into cytosol by a phenylalanine plastidial cationic amino acid transporter (PhpCAT) identified in petunia flowers by Widhalm et al. [60] (Figure 2) [61]. Flavonoids are synthesized through the phenylpropanoid pathway with a step transforming the phenylalanine into cinnamic acid and then into $p$-coumaric acid (Figure 2). These two compounds are synthesized via the phenylalanine ammonia-lyase (PAL) and cinnamate 4-hydroxylase $(\mathrm{C} 4 \mathrm{H})$, respectively. The first enzyme involved is the chalcone synthase (CHS) producing naringenin chalcone through p-coumaric acid and three malonyl-CoA. Then chalcone isomerase ( $\mathrm{CHI}$ ) leads to naringenin from which all flavonoids derive. Flavanonols (or dihydroflavonols) arise from flavanones by the intervention of flavanone 3-hydrolxylase (F3H) a key enzyme in the flavonoid pathway. $\mathrm{F} 3 \mathrm{H}$ catalyzes the oxidation of naringenin into dihydrokaempferol (colorless dihydroflavonol) that subsequently can be hydroxylated on the $3^{\prime}$ or $5^{\prime}$ position of the $\mathrm{B}$ ring, by flavonoid $3^{\prime}$-hydroxylase $\left(\mathrm{F}^{\prime} \mathrm{H}\right)$ or flavonoid $3^{\prime}, 5^{\prime}$-hydroxylase $\left(\mathrm{F}^{\prime} 5^{\prime} \mathrm{H}\right)$, producing dihydroquercetin (taxifolin) and dihydromyricetin, respectively. In addition, naringenin may be directly hydroxylated by $\mathrm{F}^{\prime} \mathrm{H}$ or $\mathrm{F}^{\prime} 5^{\prime} \mathrm{H}$ to give, respectively, eriodictyol and pentahydroxy-flavanone, which are again hydroxylated by F3H into dihydroquercetin (taxifolin) and dihydromyricetin [62] (Figure 2).

A set of enzymes involved in flavonol biosynthesis (CHS, CHI, F3H, FLS, and F3' $\mathrm{H}$ ) has been detected (for a review see Ferrer et al. [36]). Their biosynthesis is triggered in response to light and ROS stress occurring in photosystems. The three main flavonolsquercetin, kaempferol and myricetin - are formed from dihydroflavonols by the action of flavonol synthase (FLS). FLS is the most important enzyme in the biosynthesis of flavonols and it is in competition with dihydroflavonol 4-reductase (DFR) involved in the synthesis of leucoanthocyanidins [63] (Figure 2). The basic structure of flavonols (see Figure 1) is obtained by oxidation of dihydroflavonols by FLS [64].

Flavonoid biosynthesis is first regulated at genetic and transcriptional levels [65]. Such regulations have been described in various model plant species thanks to the availability of many mutants affecting the expression of several flavonoid biosynthetic genes $[66,67]$. MYB (myeloblastosis) and basic helix-loop-helix (bHLH) transcription factors, together with WD40 proteins are the main transcriptional regulators of the flavonoid biosynthetic pathway genes [68,69]. Flavonol biosynthesis is more specifically regulated by different MYBs transcription factors as identified in Arabidopsis thaliana, Prunus persica and grapevine [70-73]. In Arabidopsis, AtMYB11, AtMYB12, and AtMYB111 from the R2R3MYB gene family activate on their own the CHS, CHI, F3H, and FLS promoters [70]. Interestingly, the authors identified additional genes including UDP-glycosyltransferases 
(UGTs) and demonstrated that the accumulation of flavonol glycosides correlates with the expression domains of the different MYB factors.
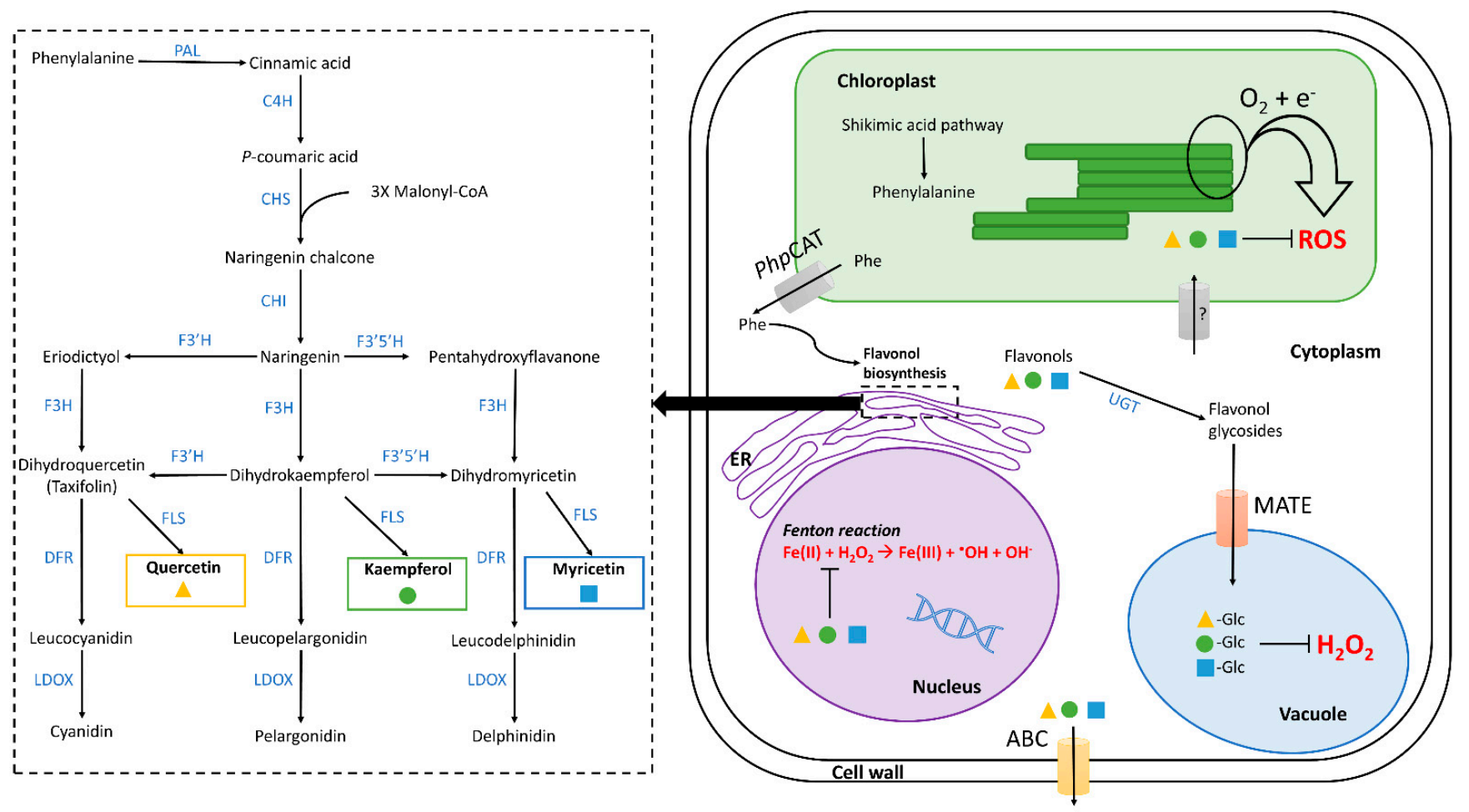

Figure 2. Biosynthesis and subcellular localization of flavonols in leave tissues. Flavonols are synthesized in the cytoplasm, on the cytosolic face of the endoplasmic reticulum (ER) (right picture). The different enzymes involved in their biosynthesis (left box) are shown in blue and flavonols are indicated and framed by different colors. The pathway shown represents the general pathway found in model plants such as Arabidopsis thaliana. The first step begins with the synthesis of phenylalanine in the chloroplasts which is then transported to the cytosol via the phenylalanine plasticial cationic amino acid transporter (PhpCAT), identified in petunia. Abbreviations are as follows: $\mathrm{C} 4 \mathrm{H}$, cinnamate 4-hydroxylase; $\mathrm{CHI}$, chalcone isomerase; $\mathrm{CHS}$, naringenin-chalcone synthase; DFR, bifunctional dihydroflavonol 4-reductase/flavanone 4-reductase; F3H, flavanone 3-hydroxylase; F3' $\mathrm{H}$, flavonoid 3'-hydroxylase; F3'5' H, flavonoid 3'5'-hydroxylase; FLS, flavonol synthase; LDOX, leucoanthocyanidin dioxygenase; PAL, phenylalanine ammonia-lyase; Phe, phenylalanine; UGT, UDP-dependent glucosyl transferase. Once synthetized, flavonols can be subjected to various modifications (glycosylation, methylation, etc.) and be stocked into vacuoles. They are transported into different compartments and through cells by MATE (multidrug and toxic compound extrusion) and ABC (ATP binding cassette) transporters families. In nucleus, vacuole, and chloroplast, flavonols will inhibit ROS accumulation.

Biosynthesis of flavonoids mainly occurs in the cytoplasm, more precisely in the cytosolic face of the endoplasmic reticulum as shown in many different species [74-76] (Figure 2). Furthermore, some of the enzymes involved in flavonol biosynthesis have been shown to co-localize in the nucleus, consistent with the idea that some flavonols are directly or indirectly involved in the protection of DNA against ROS oxidative damages in particular by supressing the Fenton reaction (i.e., sequestration of metal ions Fe(II); Figure 2) [48,77,78]. Flavonols have also been detected in chloroplasts, and a study from Zaprometov and Nikolaeva [79] concluded that chloroplasts are capable of flavonoid biosynthesis but this hypothesis needs to be confirmed by other experimental support [79,80]. The presence of antioxidant flavonols in chloroplasts could be explained because chloroplasts are a major source of ROS. Overall, the presence of flavonols in various cell compartments can be 
mainly explained by their antioxidant activities (for a review see Hernández et al. [80]), but their subcellular transport needs to be better elucidated.

Once synthesized, the end-products of the flavonoid pathway such as flavonols are transported towards various cellular organelles (i.e., vacuole, chloroplasts and nucleus; Figure 2). Intracellular transport in leaf tissues occurs primarily to the vacuoles of different cells (stomata guard cells, epidermal and subepidermal cells). Their transportation from the biosynthesis site to the storage site is driven by different transporters such as multidrug and toxic compound extrusion (MATE) [81]. In vacuoles, flavonols are mainly stored in glycosylated forms-since glycosylation increases their solubility in the aqueous cellular compartment [82] — where they have been suggested to reduce the $\mathrm{H}_{2} \mathrm{O}_{2}$ concentration [83]. Although vacuoles from epidermal cells are their main flavonol reservoirs, flavonols are also transported and stored in the cell walls of the epidermal cells as methylated flavonol glucosides [84] and within the leaf cuticle [85]. Flavonoids (including flavonols) are also synthesized and then accumulated in glandular trichomes of leaves, with higher concentrations in leaves exposed to high levels of light (as shown in the Mediterranean species Phillyrea latifolia; [86]). All these studies illustrate that flavonoids are mainly stored in the outer leaf tissues (epidermis, cuticle and outer storage structures) which optimizes their role as UV-screeners or ROS scavengers. In addition, quercetin-glycosides have been detected in the mesophyll of leaves subjected to drought stress which is consistent with their potential function as $\mathrm{H}_{2} \mathrm{O}_{2}$ scavengers [38]. Likewise, flavonoids reach the highest concentrations in leaves compared to other plant organs [87], which is related to their protective role under excess light (see Section 4). Imaging techniques, such as confocal microscopy, are used to precisely locate flavonoids within leaf tissue [88].

The transport mechanisms of flavonoids from the biosynthetic site to the storage site (within cellular organelles and tissues) but also between plant organs, remain poorly understood. The transport of flavonoids to the chloroplast is not known. Some hypotheses have been proposed for flavonoid transport including membrane vesicle-mediated transport and membrane transporter-mediated transport [89,90]. Several transporters are known to be involved in flavonoid transport such as MATE (multidrug and toxic compound extrusion) transporters cited above (for transport of flavonoids between the cytosol to the vacuole) [81,91] and the ATP binding cassette (ABC) (Figure 2) [92]. The later participate in long-distance unidirectional transport of flavonoids (e.g., naringenin, dihydrokaempferol and dihydroquercetin) between roots and shoots [93]. The transport of flavonoids between different plant organs seems crucial to respond to the various stresses undergone by the plant.

\section{Flavonols in Plants: An Important Polyphenol to Cope with Rapid Climate Change}

In the context of climate change, the increasing $\mathrm{CO}_{2}$ concentration in the atmosphere implies global warming [94] and depletion of the stratospheric ozone layer, resulting in UV-B radiation increases [95]. At the regional scale, the Mediterranean is a critical hot spot in the context of climate change due to the expected increase in surface temperatures, drought episodes and solar radiation exposure [96-98]. By the end of the twenty-first century, precipitation will decrease at a rate of around $-20 \mathrm{~mm} / \mathrm{K}($ or $-4 \% / \mathrm{K})$ in this region and temperature will warm $20 \%$ more than the global average, especially in summer (i.e., 50\% larger than global warming) [98]. A warmer climate in the Mediterranean area will also cause variations in the hydrological cycle consisting of a rise in both sea level and soil salinity [99]. Arid regions are the most prone to salinization due to the precipitation scarcity leading to low drainage of salts in soil [100]. Ultraviolet (UV) radiation, drought, warming and salinity expected in the Mediterranean region threaten plant development as they negatively impact physiological and biochemical processes, resulting in reductions in plant growth and reproduction success (fitness) [24]. To counterbalance such climatic stresses, plants develop physical and chemical defenses [101], the later being partly represented by PSMs, including polyphenols [12,102]. 
To a certain extent, Mediterranean plants are able to tolerate warming, increased drought and UV radiation excess [103]. Morphological and physiological plasticity have been observed in Mediterranean trees, shrubs and herb species (for a review see Matesanz and Valladares [103]). Plasticity differs not only among species and populations but also among traits and environmental factors. Species with high phenotypic plasticity, and in particular those able to evolve rapidly, have an evolutionary advantage, especially under rapid climate change. Among the plasticity traits, plant metabolic plasticity is crucial for resistance and adaptation to various abiotic stresses and has thus been used as an indicator of plant survival in a changing environment. Mediterranean species display very contrasting flavonoid composition and concentration [12], thus suggesting a species-specific response to climate stressors. A study of Sosa et al. [104] highlighted the diversification in composition and content of flavonoids in a same species (Cistus ladanifer) from different populations and locations (different climatic conditions). This result suggests that flavonoids could have various ecological functions strongly linked to environmental conditions. All these studies illustrate the fact that the metabolic plasticity can be an important asset for Mediterranean plants to cope with changing climate. In recent decades, various studies have demonstrated the effect of climate-related stresses on flavonoid metabolism. Some of them reveal an enhancement of flavonol production under drought, heat, UV radiation and salinity, as well as their protective role under these stress conditions as described hereafter (Table 2). These studies strongly suggest an important role of flavonols to cope with unfavorable Mediterranean environmental conditions, especially with climate change. 
Table 2. Increasing of flavonol concentration under different abiotic stresses reported in literature for different species and experimental conditions. All studies are performed on harvested leaves or roots.

\begin{tabular}{|c|c|c|c|c|c|c|c|c|}
\hline Abiotic Stress & Flavonol Type & Species & Plant Organ & $\begin{array}{c}\text { Tissue } \\
\text { Localization }\end{array}$ & $\begin{array}{l}\text { Growth } \\
\text { Conditions }\end{array}$ & $\begin{array}{l}\text { Measurement } \\
\text { Technique }\end{array}$ & Conclusion/Function & References \\
\hline Drought & Kaempferol, quercetin & Arabidopsis thaliana & Not specified (all plant) & Not studied & Growth chamber & LC-PDA-MS & $\begin{array}{l}\text { Scavenging radical activity (Quercetin } \\
\text { 3-O-glucoside and kaempferol } \\
\text { 3-O-glucoside). } \\
\text { Quercetins had a higher antioxidant } \\
\text { activity than kaempferols. }\end{array}$ & [105] \\
\hline Drought & Myricetin, kaempferol & Populus spp. & Leaves and root & Not studied & Growth chamber & HPLC-PDA & Antioxidant capacity. & {$[106]$} \\
\hline Drought & Kaempferol, quercetin & Trifolium repens $\mathrm{L}$. & Leaves & Not studied & Field conditions & HPLC & $\begin{array}{l}\text { Under drought stress, kaempferol } \\
\text { glycosides accumulation was related to } \\
\text { reduced senescence and to less } \\
\text { pronounced decreases in shoot } \\
\text { dry weight. }\end{array}$ & [107] \\
\hline $\begin{array}{l}\text { Drought and } \\
\text { UV radiation }\end{array}$ & Quercetin & Fraxinus ornus & Leaves & $\begin{array}{l}\text { Mesophyll (in the } \\
\text { vacuoles of cells) }\end{array}$ & $\begin{array}{l}\text { Grown outdoors in an } \\
\text { experimental plot }\end{array}$ & $\begin{array}{l}\text { Confocal microscope } \\
\text { for flavonol } \\
\text { localization. HPLC-MS } \\
\text { for quantification. }\end{array}$ & $\begin{array}{l}\text { Increase in quercetin 3-O-glucoside in } \\
\text { severe drought and excess light stresses. } \\
\text { Potential function as } \mathrm{H}_{2} \mathrm{O}_{2} \text { scavenger. }\end{array}$ & {$[38]$} \\
\hline UV radiation & Kaempferol & Picea abies & Needles & Not studied & $\begin{array}{l}\text { Field cabinet } \\
\text { experiments }\end{array}$ & RP-HPLC & Potentially UV-B screening. & {$[108]$} \\
\hline UV radiation & Kaempferol, quercetin & Arabidopsis thaliana & Leaves & Not studied & Growth chamber & UPLC-TQD & Antioxidant activity. & [109] \\
\hline UV radiation & Kaempferol, quercetin & Arabidopsis thaliana & Leaves & Not studied & Growth chamber & UPLC-MS & $\begin{array}{l}\text { Accumulation of specific flavonol } \\
\text { glycosides, i.e., kaempferol and } \\
\text { quercetin di- and triglycosides } \\
\text { (rhamnosylated) in response to } \\
\text { UV-radiation. }\end{array}$ & [110] \\
\hline UV radiation & $\begin{array}{l}\text { Myricetin and } \\
\text { quercetin }\end{array}$ & Cistus incanus L. & Leaves & Not studied & Field conditions & HPLC-DAD & $\begin{array}{l}\text { Major light-induced increases observed } \\
\text { for myricetin and quercetin derivatives. }\end{array}$ & [111] \\
\hline Low temperature & $\begin{array}{l}\text { Quercetin, kaempferol } \\
\text { and rhamnetin }\end{array}$ & Quercus ilex $\mathrm{L}$. & Leaves & Not studied & Field conditions (forest) & HPLC-MS/MS & $\begin{array}{l}\text { High amount of flavonol-hexosides } \\
\text { detected in winter. They could } \\
\text { contribute to photoprotection. }\end{array}$ & {$[112]$} \\
\hline Heat and drought & Kaempferol, quercetin & $\begin{array}{l}\text { Citrus spp. (Cleopatra } \\
\text { and Carrizo) }\end{array}$ & Leaves & Not studied & Greenhouses & UPLC/ESI-QTOF-MS & $\begin{array}{l}\text { Combination of heat and drought } \\
\text { favours accumulation of kaempferol } \\
\text { and quercetin derivatives in } \\
\text { poorly-drought tolerant species. }\end{array}$ & [113] \\
\hline Heat and salinity & Kaempferol, quercetin & Solanum lycopersicon $\mathrm{L}$. & Leaves & Not studied & $\begin{array}{l}\text { In vitro (using aerated } \\
\text { hydroponic systems } \\
\text { containing a modified } \\
\text { Hoagland solution) }\end{array}$ & UHPLC/QTOF-MS & $\begin{array}{l}\text { Accumulation of kaempferol and } \\
\text { quercetin derivatives leads to lower } \\
\text { oxidative damage when plant grow } \\
\text { under concomitant heat and salt stress. }\end{array}$ & [114] \\
\hline
\end{tabular}


Table 2. Cont.

\begin{tabular}{|c|c|c|c|c|c|c|c|c|}
\hline Abiotic Stress & Flavonol Type & Species & Plant Organ & $\begin{array}{c}\text { Tissue } \\
\text { Localization }\end{array}$ & $\begin{array}{c}\text { Growth } \\
\text { Conditions }\end{array}$ & $\begin{array}{l}\text { Measurement } \\
\text { Technique }\end{array}$ & Conclusion/Function & References \\
\hline $\begin{array}{l}\text { Salinity and } \\
\text { UV-radiation }\end{array}$ & Quercetin & Ligustrum vulgare & Leaves & $\begin{array}{c}\text { Epidermal, boundary } \\
\text { of epidermal and } \\
\text { adaxial palisade, and in } \\
\text { the palisade } \\
\text { parenchyma cell layers }\end{array}$ & Greenhouses & $\begin{array}{c}\text { Epifluorescence } \\
\text { microscope and } \\
\text { Confocal Laser } \\
\text { Scanning Microscope } \\
\text { (CLSM) for flavonoids } \\
\text { localization. HPLC for } \\
\text { quantification. }\end{array}$ & $\begin{array}{l}\text { Increase in quercetin 3-O-glycoside in } \\
\text { response to UV-radiation and salinity } \\
\text { stress (NaCl). } \\
\text { Potential role as antioxidant and } \\
\text { photoprotection. }\end{array}$ & [115] \\
\hline Salinity & Kaempferol, quercetin & Casuarina glauca & $\begin{array}{l}\text { Nodules, roots and } \\
\text { branchets }\end{array}$ & Not studied & $\begin{array}{c}\text { In vitro (using } \\
\text { Broughton and } \\
\text { Dillworth's medium) }\end{array}$ & LC-HRMS & $\begin{array}{l}\text { Kaempferol and quercetin derivatives } \\
\text { accumulate in case of severe salt stress } \\
\text { and play a key role in protection against } \\
\text { oxidative damage. }\end{array}$ & [116] \\
\hline Salinity & Kaempferol, quercetin & Apocynum venetum $\mathrm{L}$. & Leaves & Not studied & Plant culture room & HPLC & $\begin{array}{l}\text { Kaempferol and quercetin } \\
\text { accumulation under salt stress. }\end{array}$ & [117] \\
\hline
\end{tabular}

Abbreviations: HPLC: High-performance liquid chromatography; HPLC-DAD: High-performance liquid chromatography-diode array detection; HPLC-MS: High-performance liquid chromatography-mass spectrometry; HPLC-PDA: High-performance liquid chromatography-photodiode array detection; LC-HRM: Liquid chromatography-high resolution metabolomics; LC-PDA-MS: Liquid chromatography-photodiode-array-mass spectrometry; RP-HPLC: Reverse phase-high performance liquid chromatography; UHPLC/QTOF-MS: Ultra-high performance liquid chromatography-quadrupole time-of-flight mass spectrometry. UPLC/ESI-QTOF-MS: Ultra performance liquid chromatography/Electrospray-ionizationquadrupole time-of-flight mass spectrometry; UPLC-MS: Ultra Performance Liquid Chromatography-mass spectrometry; UPLC-TQD: Ultra Performance Liquid Chromatographytandem Quadrupol. 


\subsection{Drought}

Flavonol concentrations increase under drought stress as found in several species [118-121]. A recent study on the model species Arabidopsis thaliana has also confirmed by transcriptomic evidence the enhancement of flavonol metabolism under drought conditions [105]. In fact, drought regulates key genes coding for the enzymatic activity involved in flavonol biosynthesis such as chalcone isomerase $(\mathrm{CHI})$, flavonoid $3^{\prime}$-hydroxylase $\left(\mathrm{F}^{\prime} \mathrm{H}\right)$, flavanone 3-hydroxylase $(\mathrm{F} 3 \mathrm{H})$ and flavonol synthase (FLS) which results in increased flavonol concentrations [122,123] (Figure 2). Moreover, it has been shown that some transcription factors such as MYB and bHLH families play a role in the accumulation of flavonoids resulting in enhanced drought tolerance $[124,125]$. It is also now known that there exists a relationship between aglycone/glycone flavonols and the oxidative stress, the glycosylated forms of flavonols being less effective antioxidants $[54,55]$. Despite their contrasting antioxidant protection, an accumulation of quercetin 3-O-glucosides and a decrease in the antioxidant enzyme activity have been observed under water stress in leaves of the Mediterranean species Fraxinus ornus, suggesting that these glycoside forms of flavonols could act as $\mathrm{H}_{2} \mathrm{O}_{2}$ scavengers during water stress [38]. The precise role of flavonoid glycosylation under drought remains complex to evaluate because of the signaling crosstalk between flavonoid production and stress response. Other recent studies also highlight the sensitivity of flavonol concentration in response to drought in different Mediterranean tree species such as Pinus pinaster Ait. and Quercus ilex L. [14,15,126]. All these studies support the idea that increasing foliar concentration of flavonoids is a key defense strategy under water depletion. They also reveal the strong capacity of Mediterranean species to reinforce the flavonoid metabolism to cope with drought.

\subsection{Warming}

Warming, expected to be paralleled by aggravated drought in the Mediterranean region, is an important stress factor affecting plant growth and survival [127]. In plants, many biochemical reactions are sensitive to temperature, the stress from which varies according to the pic of temperature reached and duration [128]. As a consequence of heat, leaf water status and stomatal conductance are affected, resulting in a higher ROS production [129]. Temperature has a high influence on flavonoid metabolism, especially on anthocyanin accumulation which is reduced in response to high temperatures, as shown in grapevine and apple fruit [130-132]. In shrub and a conifer species, recent studies have reported an effect of enhanced temperature which leads to a reduction in flavonoids in stems [133] and leaves [134,135], this being related to an increase in plant growth. In those studies, results support the theory that under non-limiting resources, plants exposed to a moderate elevated temperature will use carbon for growth rather than for synthesis of defense compounds [136].

Concerning Mediterranean species, they have developed a wide range of adaptative traits to survive to summer climate conditions, including both elevated temperatures and drought [137]. For example, several studies have been conducted on the typically Mediterranean species, Cistus ladanifer L., whose leaves and stems secrete an exudate rich in secondary metabolites, in particular flavonoids [138,139]. Seasonality, closely related to temperatures, influences strongly flavonols content in C. ladanifer L. [139,140]. The maximum secretion of flavonoids in the exudate of this species is produced during summer when plants suffer the most from high temperatures, and also UV irradiation and water stress [140]. Few recent studies reported the effect of warming on the concentration of phenolics, especially when combined with others stress such as drought $[113,141]$. The study of Zandalinas et al. [113] on Citrus plants highlighted that the combination of water stress and heat stress lead to higher levels of flavonols (i.e., kaempferol derivates) than in heat stress only. These findings are particularly interesting as the combination of drought and heat is the most recurrent condition in Mediterranean regions. It has also been reported in a typical Mediterranean tree species (Quercus ilex L.) that in winter (at the lowest temperatures), flavonol contents were the highest [112]. The highest amount of flavonols in this season can be explained by their contribution to photoprotection as in 
winter low photosynthetic activity and low excess energy dissipation can increase the risk of photodamage. Despite all this evidence about the role flavonoids play in Mediterranean plant adaptation to environmental changes, future studies need to address their efficiency when these changes operate rapidly.

\subsection{UV Radiation}

High solar radiation is one of the most important changes plants will have to cope with under future climate change [142]. UV radiation is generally divided into three classes based on the light wavelength: UV-C (<280 nm), UV-B (280-315 nm), and UV-A (315-400 nm) [143]. Flavonols have largely been considered as an important role in UV protection by inhibiting ROS generation, and ROS quenching once they are formed [28,37,115]. In addition, as many other flavonoids, they have the capacity to absorb solar wavelengths in the range between 280 and $320 \mathrm{~nm}$ (UV-B) [37]. However, in the recent past, the idea of flavonols as the most effective UV-B absorbers has been questioned $[27,115,144]$. Due to their tissue distribution, often on leaf surface (e.g., cuticle, trichomes), they could act as UV-screening, but photoprotection is possibly not their most important function $[27,109,145]$. UV-induced increases in the ratio of dihydroxy to monohydroxy B-ring substituted flavonols glycosides (such as quercetin to kaempferol ratios) as reported in different plant species exposed to various proportions of UV radiation [144,146-148]. Indeed, kaempferol and quercetin are both able to absorb light in the UV-A and UV-B regions, but they present variations in their ROS scavenging properties. The dihydroxylated B-ring of quercetin provides increased antioxidant activity relative to the monohydroxylated ring of kaempferol which explains the higher accumulation of quercetin than kaempferol under oxidative stresses [46,149]. In addition, a screening advantage for quercetin glycosides over kaempferol glycosides could be due to the higher capacity of quercetin glycosides to dissipate UV-B excitation energy through tautomerization [40].

A recent study from Hectors et al. [110] highlighted the role of the rhamnosylated kaempferol and quercetin glycosides during UV acclimation in Arabidopsis thaliana. The concentration of these compounds increased because of UV-stress and the resulting oxidative stress. However, the biological role of these flavonol derivatives remains unclear as they feature less effective antioxidant activity than their aglycone forms [54,55]. It has thus been suggested that accumulation of flavonol glycosides constitutes a reserve of flavonols which can be used during long-term UV acclimation and does not represent the first line response upon exposure to UV radiation [37]. Studies on Mediterranean plants species usually report a concentration of dihydroxy B-ring-substituted flavonols (quercetin) greater than that of monohydroxy-flavonols (kaempferol) under excess light and drought stress [8,9,38]. The higher concentration of quercetin in Mediterranean plants compared to kaempferol is probably related to their high adaptation to light exposure as quercetin is an excellent antioxidant [31]. Comparatively, the reverse is observed in shaded plants with a decrease in the quercetin: kaempferol ratio [144,150].

\subsection{Salinity}

Soil salinity may occur for two reasons: natural accumulation of salt in the soil over long periods or human-induced accumulation due to activities that change the hydrologic soil balance [151]. In Mediterranean regions, increasing crop irrigation is crucial to cope with the drier climate but it often causes soil salinization because water used for irrigation is groundwater whose high salinization is due to seawater intrusion [152]. In addition, the natural accumulation of salt in the soil can be due to poor precipitation, which can be observed in Mediterranean regions, resulting in lower drainage of soil water. In plants, the excess of salt in soils reduces their ability to uptake water and competes with the mineral nutrient metabolism reducing plant growth [153,154]. Under salt stress, a reduction in photosynthesis is observed due to the reduction in water potential $[155,156]$. In fact, salt stress can lead to stomatal closure reducing $\mathrm{CO}_{2}$ uptake by leaves thereby exposing chloroplast to an excess of energy leading to the generation of ROS and leaf oxidative 
damage [157]. Salt stress and water deficit stress show a high degree of similarity in physiological, biochemical and molecular responses, probably due to the fact that salt stress brings osmotic effects [158]. As shown in many studies, salinity stress induces flavonol accumulation to mitigate oxidative stress $[159,160]$. These results are also supported by genomic evidence where key genes of the flavonol pathway were upregulated under salt stress (e.g., FLS, F3'H and F3H) $[117,161]$.

Salt stress' effect on flavonoid contents in Mediterranean species remains poorly documented. Tattini et al. [162] have described the response of salinity on three different evergreen Mediterranean species (Olea europaea L., Phillyrea latifolia L. and Pistacia lentiscus L.) which are widely distributed in dry coastal areas of the Mediterranean basin, where soil salinity concentrations accumulate especially during the warm summer season. In the two least salt stress-tolerant species (i.e., O. europaea and P. latifolia), phenylpropanoid metabolism was upregulated compared to the species that better utilizes $\mathrm{Na}^{+}$and $\mathrm{Cl}^{-}$for osmotic adjustment (P. lentiscus). The most salinity-sensitive species reduced their growth more than the most resistant species to better devote their energy to antioxidant defenses (i.e., flavonoid biosynthesis).

\section{Flavonols as Antioxidants: A Unifying Mode of Action against Climate Stresses}

All factors previously described (light, high temperatures, water deficit and salinity), trigger ROS production under stress conditions overwhelming the scavenging mechanisms of the antioxidant system in plants and eventually leading to several cellular damages including alteration of DNA which can cause cell death [163]. Major sites of ROS production in plants are located in the chloroplast, mitochondria and peroxisomes [164].

Flavonol biosynthesis is almost exclusively enhanced due to triggered ROS formation associated with oxidative stress $[19,28]$. The major source of ROS production occurs during the photosynthetic electron transport system. In case of drought stress, partial or total stomatal closure allows plants to reduce evapotranspiration but also limits the entrance of $\mathrm{CO}_{2}$ and thus net photosynthesis leading to an excess of unused light energy and perturbation in the chloroplastic electron chain since chloroplasts continue to absorb light energy. As a result, leaf cells produce a significant rise of ROS [165]. An imbalance is created within the photosynthetic reactions because the energy supply (NADPH, ATP) exceeds the demand and electron acceptors become depleted. These electrons are transferred to oxygen, resulting in the production of ROS [166] which include superoxide $\left(\mathrm{O}_{2}{ }^{-}\right)$, hydrogen peroxide $\left(\mathrm{H}_{2} \mathrm{O}_{2}\right)$, hydroxyl radical $\left({ }^{\bullet} \mathrm{OH}\right)$, singlet oxygen $\left({ }^{1} \mathrm{O}_{2}\right)$ and perhydroxyl radical $\left(\mathrm{HO}_{2}^{\bullet}\right)$ [83].

The main explanation for flavonols acting as antioxidant relies on the high reactivity of their hydroxyl substituents as shown in the following reaction [44]:

$$
\mathrm{F}-\mathrm{OH}+\mathrm{R}^{\bullet} \rightarrow \mathrm{F}-\mathrm{O}^{\bullet}+\mathrm{RH}
$$

Specifically, the B-ring hydroxyl structure is the main driver of flavonoid potential to scavenge ROS [44]. Flavonols are greatly antioxidant because of their ability to donate electrons or hydrogen atoms. They act as antioxidants by several mechanisms. The first on is direct scavenging of ROS, as described in the reaction above. They also inhibit ROS formation through the chelation of metals. For example, quercetin present a strong capacity to chelate ions of metals such as $\mathrm{Fe}$ and $\mathrm{Cu}$-ions thus preventing free radical formation including the damaging ROS [32,33]. Due to their specific structure, in particular the hydroxyl groups, flavonols can form metal flavonol complexes [167]. They also can inhibit the enzymes that participate in the generation of free radicals (e.g., glutathione S-transferase and NADH oxidase), or potentially activate some antioxidant enzymes possessing radical scavenging capacity $[19,34,168]$.

To determine the potential role of flavonols in planta, in vitro assays were first performed, showing that flavonols can directly scavenge ROS [31]. However, data supporting their role as ROS scavengers in living plants remain poorly documented (for a review of effective role of flavonoids as antioxidant in plants see Agati et al. [86]). More recently, 
studies performed under controlled conditions in laboratory on the model plant Arabidopsis thaliana and some crop species have correlated the increase in flavonols and the decrease in ROS, suggesting an antioxidant role of flavonols under stress conditions [106,109].

\section{Flavonols as Indirect Growth Regulators}

Phytohormones allow coordination of the biosynthesis of defense compounds such as flavonoids during abiotic stress response [169] (Figure 3). The main phytohormones involved in abiotic stress responses are auxins, abscisic acid (ABA), salicylic acid (SA), jasmonic acid (JA) and ethylene (ET) [170]. There is clear evidence showing that flavonoids, as modulators of the ROS-signaling cascade, modify in turn, the phytohormone signals such as auxins and ABA [21,35].

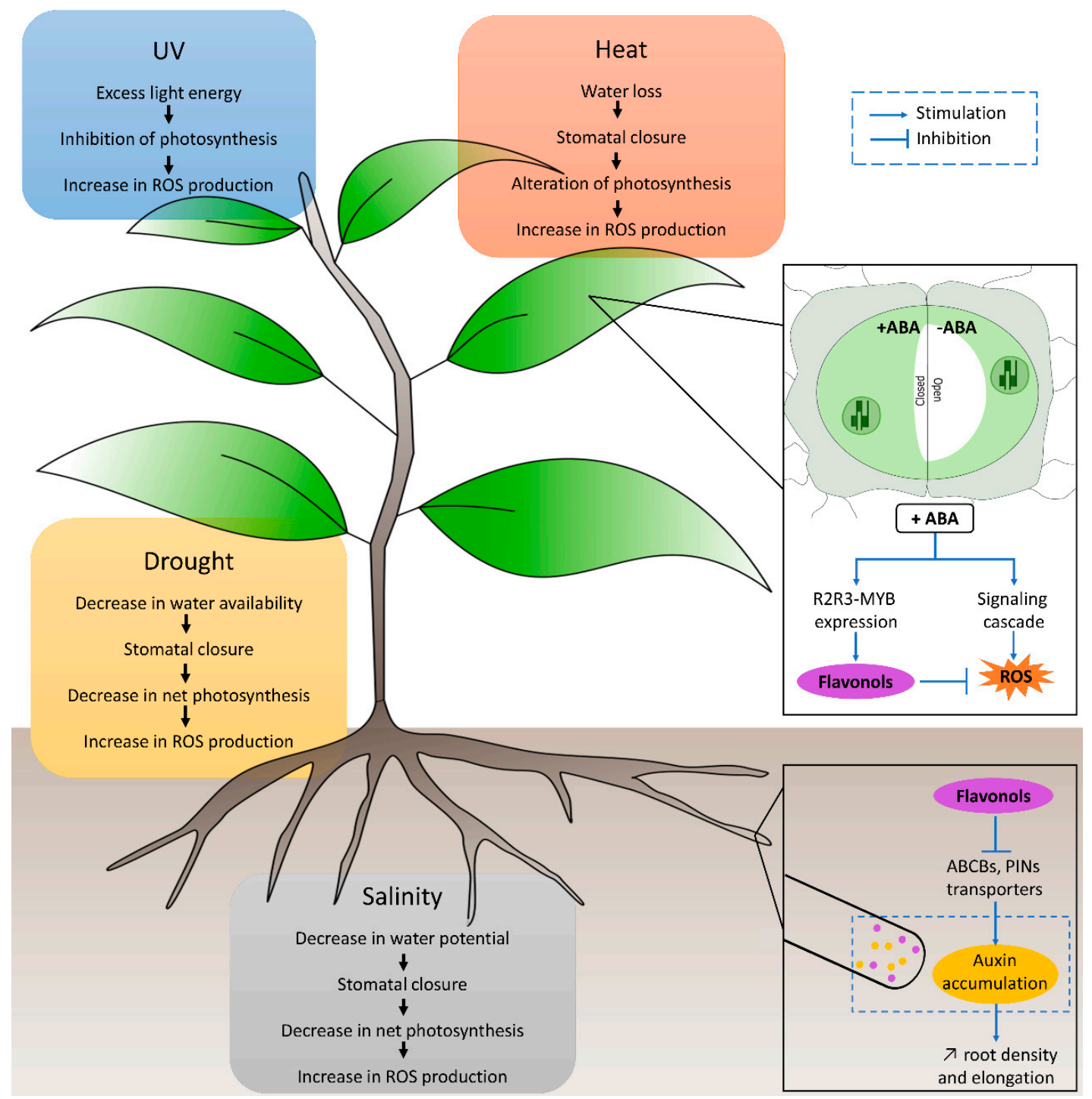

Figure 3. Plant responses to abiotic stress. The colored boxes summarize the four abiotic stresses referred to in this review and their main consequences for plant physiology. Flavonols' role as ROS scavengers and their interaction with the phytohormones ABA in leaves and auxin in roots is shown in black boxes. In leaves, the opening of stomata is allowed by the binding of ABA to membrane receptors resulting in an efflux of ions and therefore an efflux of water leading to stomata closure. ABA act on the R2R3-MYB gene by enhancing its expression thus stimulating flavonol biosynthesis. It also triggers a signaling cascade leading to ROS production. In roots, flavonols inhibit auxin transport leading to auxin accumulation and root elongation. 
Auxins are well-known phytohormones involved in developmental processes like growth elongation, root formation and plant tropisms in response to gravity (gravitropism) or light (phototropism) [171]. An in vitro study of Jacobs et al. [172] showed that flavonols (e.g., quercetin and kaempferol) compete with a synthetic auxin transporter inhibitor known as naphthylphthalamic acid (NPA) and can perturb auxin transport in a variety of plant tissues. Later, flavonoids' role as negative regulators of auxin transport was proven in vivo in Arabidopsis thaliana mutants [173-175]. In vivo experiments on Arabidopsis thaliana shoots showed that a specific flavonol bis-glycoside (i.e., kaempferol 3-O-rhamnoside-7O-rhamnoside) acted as an endogenous polar auxin transport inhibitor thus reducing plant stature [176]. The mechanism whereby flavonols regulate auxin transport has been explored in many studies and it includes several processes. For example, quercetin reduced the auxin transport capacity of ATP-binding cassette type B (ABCB) families [21]. Furthermore, flavonols can regulate PIN function, which are a protein family of auxin efflux transporters $[35,177]$ (Figure 3 ). In addition, flavonols might affect auxin transport by changing the level of ROS which have been reported to modulate polar auxin transport (i.e., polar auxin transport is altered in plants with ROS accumulation) [178]. On the other hand, auxins control flavonol biosynthesis. Auxins control WRKY23 and MYB12 transcription factors thus increasing the accumulation of flavonols and proper root growth and development $[179,180]$. By regulating auxin flows, flavonols play a key role in responses to abiotic stresses because they influence auxin distribution and thus take part in the control of plant organ development in response to water deficit, salinity or other stress factors. For example, auxin's accumulation positively modulates root architecture especially the lateral root number [181].

Various studies have found that flavonols played a role in UV acclimation by regulating auxin movement and catabolism thus leading to UV-induced morphogenic responses refs. $[27,56,150,182]$. Moreover, better tolerance to stress may also be due to the interaction of many other hormones such as abscisic acid (ABA) with auxins resulting in the maintenance of root growth [183].

ABA is a phytohormone considered as a plant stress hormone because it plays an important role in integrating various stress signals and controlling downstream stress responses [184]. In abiotic stress, ABA plays a crucial role by regulating various physiological processes such as stomatal closure, dormancy, germination, vegetative growth and modulation of root architecture, thus conferring adaptation to drought, salt and other osmotic stresses [185]. In plants, there is an ABA flavonol relationship in which ABA regulates flavonol biosynthesis and flavonols regulate the ABA-signaling network as well [186]. At the genetic level, ABA signaling regulates the expression of the R2R3-MYB gene family which are highly responsive to light irradiance and redox-controlled [187]. MYB genes are also known to be the main transcriptional regulators of the flavonoid biosynthetic pathway genes [68] which highlights the link between the ABA signaling pathway and flavonoid biosynthesis. Although the regulation of flavonol biosynthesis by the ABA signaling pathway remains poorly documented, there is recent evidence showing that flavonols, especially quercetin derivates, may regulate the ABA signaling pathway [188]. This later study is based on the fact that in guard cells, $\mathrm{ABA}$ induces a signaling cascade including the synthesis of ROS thus regulating stomatal closure [189]. However, in response to osmotic stress, ROS signaling must be rapid, but it also requires ROS scavenging by flavonols to limit cell damage. Indeed, it showed that quercetin accumulated in stomata guard cells was related to the decrease in $\mathrm{ROS}$ (i.e., $\mathrm{H}_{2} \mathrm{O}_{2}$ ) which are required to close stomata in response to ABA [190]. These signaling cascades involving complex interaction of ABA-induced ROS and flavonols is a crucial mechanism to understand the control of stomatal aperture, especially in stress conditions such as drought (Figure 3).

\section{Conclusions}

Although the precise role of polyphenols in plants remains complex to evaluate (because of the signaling crosstalk between their production and stress response) there 
is abundant evidence to support that flavonoids, especially flavonols, confer protection and indirectly regulate plant growth under abiotic stress. Enhancement of the flavonoid metabolism and eventually their production under climatic stress conditions can thereby be interpreted as an improvement of the chemical defense system in the plant. While flavonoid-related research studies have mostly used experimental designs integrating a single stress under controlled conditions, we suggest future research directions should consider field experiments where the response of the flavonoid metabolism is studied under a combination of abiotic stress, such as drought and warming in the Mediterranean ecosystems since such a scenario, rather than drought alone, will occur frequently in this region. Since these unprecedently rapid changes will probably affect Mediterranean terrestrial ecosystems dramatically, this type of study is necessary to anticipate the degree of protection chemical defenses may confer to Mediterranean species. To face such conditions, plants rich in PSM such as flavonoids with antioxidant functions will likely present competitive advantages over species with little investment in these defenses.

Author Contributions: Conceptualization, J.L., E.O. and C.F.; writing, J.L. and E.O.; review and editing, J.L., E.O. and C.F. All authors have read and agreed to the published version of the manuscript.

Funding: This study was carried out within the METAPHORES project funded by CNRS (MITI and DGDS). Grant agreement No. 250892.

Institutional Review Board Statement: Not applicable.

Informed Consent Statement: Not applicable.

Data Availability Statement: Not applicable.

Conflicts of Interest: The authors declare no conflict of interest.

\section{References}

1. Yang, L.; Wen, K.-S.; Ruan, X.; Zhao, Y.-X.; Wei, F.; Wang, Q. Response of Plant Secondary Metabolites to Environmental Factors. Molecules 2018, 23, 762. [CrossRef] [PubMed]

2. Crozier, A.; Jaganath, I.B.; Clifford, M.N. Phenols, Polyphenols and Tannins: An Overview. In Plant Secondary Metabolites: Occurrence, Structure and Role in the Human Diet; Crozier, A., Clifford, M.N., Ashihara, H., Eds.; Blackwell Publising: Oxford, UK, 2006; pp. 1-22.

3. Treutter, D. Significance of Flavonoids in Plant Resistance: A Review. Environ. Chem. Lett. 2006, 4, 147. [CrossRef]

4. Gori, A.; Tattini, M.; Centritto, M.; Ferrini, F.; Marino, G.; Mori, J.; Guidi, L.; Brunetti, C. Seasonal and Daily Variations in Primary and Secondary Metabolism of Three Maquis Shrubs Unveil Different Adaptive Responses to Mediterranean Climate. Conserv. Physiol. 2019, 7, coz070. [CrossRef]

5. Gori, A.; Nascimento, L.B.; Ferrini, F.; Centritto, M.; Brunetti, C. Seasonal and Diurnal Variation in Leaf Phenolics of Three Medicinal Mediterranean Wild Species: What Is the Best Harvesting Moment to Obtain the Richest and the Most Antioxidant Extracts? Molecules 2020, 25, 956. [CrossRef]

6. Moreira, X.; Castagneyrol, B.; Abdala-Roberts, L.; Berny-Mier y Teran, J.C.; Timmermans, B.G.H.; Bruun, H.H.; Covelo, F.; Glauser, G.; Rasmann, S.; Tack, A.J.M. Latitudinal Variation in Plant Chemical Defences Drives Latitudinal Patterns of Leaf Herbivory. Ecography 2018, 41, 1124-1134. [CrossRef]

7. Moreira, X.; Mooney, K.A.; Rasmann, S.; Petry, W.K.; Carrillo-Gavilán, A.; Zas, R.; Sampedro, L. Trade-Offs between Constitutive and Induced Defences Drive Geographical and Climatic Clines in Pine Chemical Defences. Ecol. Lett. 2014, 17, 537-546. [CrossRef]

8. Tattini, M.; Galardi, C.; Pinelli, P.; Massai, R.; Remorini, D.; Agati, G. Differential Accumulation of Flavonoids and Hydroxycinnamates in Leaves of Ligustrum vulgare under Excess Light and Drought Stress. New Phytol. 2004, 163, 547-561. [CrossRef]

9. Tattini, M.; Gravano, E.; Pinelli, P.; Mulinacci, N.; Romani, A. Flavonoids Accumulate in Leaves and Glandular Trichomes of Phillyrea latifolia Exposed to Excess Solar Radiation. New Phytol. 2000, 148, 69-77. [CrossRef]

10. Tattini, M.; Remorini, D.; Pinelli, P.; Agati, G.; Saracini, E.; Traversi, M.L.; Massai, R. Morpho-anatomical, Physiological and Biochemical Adjustments in Response to Root Zone Salinity Stress and High Solar Radiation in Two Mediterranean Evergreen Shrubs, Myrtus communis and Pistacia lentiscus. New Phytol. 2006, 170, 779-794. [CrossRef]

11. Tattini, M.; Matteini, P.; Saracini, E.; Traversi, M.L.; Giordano, C.; Agati, G. Morphology and Biochemistry of Non-Glandular Trichomes in Cistus salvifolius L. Leaves Growing in Extreme Habitats of the Mediterranean Basin. Plant Biol. 2007, 9, 411-419. [CrossRef] [PubMed]

12. Di Ferdinando, M.; Brunetti, C.; Agati, G.; Tattini, M. Multiple Functions of Polyphenols in Plants Inhabiting Unfavorable Mediterranean Areas. Environ. Exp. Bot. 2014, 103, 107-116. [CrossRef] 
13. Hernández, I.; Alegre, L.; Munné-Bosch, S. Drought-Induced Changes in Flavonoids and Other Low Molecular Weight Antioxidants in Cistus Clusii Grown under Mediterranean Field Conditions. Tree Physiol. 2004, 24, 1303-1311. [CrossRef] [PubMed]

14. Rivas-Ubach, A.; Gargallo-Garriga, A.; Sardans, J.; Oravec, M.; Mateu-Castell, L.; Pérez-Trujillo, M.; Parella, T.; Ogaya, R.; Urban, O.; Peñuelas, J. Drought Enhances Folivory by Shifting Foliar Metabolomes in Quercus ilex Trees. New Phytol. 2014, 202, 874-885. [CrossRef]

15. De Miguel, M.; Guevara, M.Á.; Sánchez-Gómez, D.; de María, N.; Díaz, L.M.; Mancha, J.A.; Fernández de Simón, B.; Cadahía, E.; Desai, N.; Aranda, I.; et al. Organ-Specific Metabolic Responses to Drought in Pinus pinaster Ait. Plant Physiol. Biochem. 2016, 102, 17-26. [CrossRef]

16. Santos, E.L.; Maia, B.; Ferriani, A.P.; Teixeira, S.D. Flavonoids: Classification, Biosynthesis and Chemical Ecology. In Flavonoids from Biosynthesis to Human Health; Justino, C.G., Ed.; InTech: London, UK, 2017; Volume 6, pp. 3-17.

17. Panche, A.N.; Diwan, A.D.; Chandra, S.R. Flavonoids: An Overview. J. Nutr. Sci. 2016, 5, e47. [CrossRef]

18. Pandey, K.B.; Rizvi, S.I. Plant Polyphenols as Dietary Antioxidants in Human Health and Disease. Oxidative Med. Cell. Longev. 2009, 2, 270-278. [CrossRef] [PubMed]

19. Kumar, S.; Pandey, A.K. Chemistry and Biological Activities of Flavonoids: An Overview. Sci. World J. 2013, $2013,162750$. [CrossRef] [PubMed]

20. Taylor, L.P.; Grotewold, E. Flavonoids as Developmental Regulators. Curr. Opin. Plant Biol. 2005, 8, 317-323. [CrossRef] [PubMed]

21. Peer, W.A.; Murphy, A.S. Flavonoids and Auxin Transport: Modulators or Regulators? Trends Plant Sci. 2007, 12, 556-563. [CrossRef]

22. Morita, Y.; Takagi, K.; Fukuchi-Mizutani, M.; Ishiguro, K.; Tanaka, Y.; Nitasaka, E.; Nakayama, M.; Saito, N.; Kagami, T.; Hoshino, A.; et al. A Chalcone Isomerase-like Protein Enhances Flavonoid Production and Flower Pigmentation. Plant J. 2014, 78, $294-304$. [CrossRef]

23. Gayomba, S.R.; Watkins, J.M.; Muday, G.K. Flavonols Regulate Plant Growth and Development through Regulation of Auxin Transport and Cellular Redox Status. Recent Adv. Polyphen. Res. 2016, 5, 143-170.

24. Sharma, A.; Shahzad, B.; Rehman, A.; Bhardwaj, R.; Landi, M.; Zheng, B. Response of Phenylpropanoid Pathway and the Role of Polyphenols in Plants under Abiotic Stress. Molecules 2019, 24, 2452. [CrossRef] [PubMed]

25. Lattanzio, V.; Lattanzino, V.M.T.; Cardinali, A. Role of Phenolics in the Resistance Mechanisms of Plants against Fungal Pathogens and Insects. Phytochem. Adv. Res. 2006, 661, 23-67.

26. Naikoo, M.I.; Dar, M.I.; Raghib, F.; Jaleel, H.; Ahmad, B.; Raina, A.; Khan, F.A.; Naushin, F. Chapter 9-Role and Regulation of Plants Phenolics in Abiotic Stress Tolerance: An Overview. In Plant Signaling Molecules; Khan, M.I.R., Reddy, P.S., Ferrante, A., Khan, N.A., Eds.; Woodhead Publishing: Southston, UK, 2019; pp. 157-168.

27. Agati, G.; Tattini, M. Multiple Functional Roles of Flavonoids in Photoprotection. New Phytol. 2010, 186, 786-793. [CrossRef]

28. Agati, G.; Azzarello, E.; Pollastri, S.; Tattini, M. Flavonoids as Antioxidants in Plants: Location and Functional Significance. Plant Sci. 2012, 196, 67-76. [CrossRef] [PubMed]

29. Barnes, P.W.; Tobler, M.A.; Keefover-Ring, K.; Flint, S.D.; Barkley, A.E.; Ryel, R.J.; Lindroth, R.L. Rapid Modulation of Ultraviolet Shielding in Plants Is Influenced by Solar Ultraviolet Radiation and Linked to Alterations in Flavonoids. Plant Cell Environ. 2016, 39, 222-230. [CrossRef]

30. Davies, K.M.; Albert, N.W.; Zhou, Y.; Schwinn, K.E. Functions of Flavonoid and Betalain Pigments in Abiotic Stress Tolerance in Plants. Annu. Plant Rev. Online 2018, 1, 21-62. [CrossRef]

31. Rice-Evans, C.; Miller, N.; Paganga, G. Antioxidant Properties of Phenolic Compounds. Trends Plant Sci. 1997, 2, 152-159. [CrossRef]

32. Brown, E.J.; Khodr, H.; Hider, C.R.; Rice-Evans, C.A. Structural Dependence of Flavonoid Interactions with Cu ${ }^{2+}$ Ions: Implications for Their Antioxidant Properties. Biochem. J. 1998, 330, 1173-1178. [CrossRef]

33. Leopoldini, M.; Russo, N.; Chiodo, S.; Toscano, M. Iron Chelation by the Powerful Antioxidant Flavonoid Quercetin. J. Agric. Food Chem. 2006, 54, 6343-6351. [CrossRef]

34. Agrawal, A.D. Pharmacological Activities of Flavonoids: A Review. Int. J. Pharm. Sci. Nanotechnol. 2011, 4, 1394-1398. [CrossRef]

35. Brunetti, C.; Fini, A.; Sebastiani, F.; Gori, A.; Tattini, M. Modulation of Phytohormone Signaling: A Primary Function of Flavonoids in Plant-Environment Interactions. Front. Plant Sci. 2018, 9, 1042. [CrossRef]

36. Ferrer, J.-L.; Austin, M.B.; Stewart, C.; Noel, J.P. Structure and Function of Enzymes Involved in the Biosynthesis of Phenylpropanoids. Plant Physiol. Biochem. 2008, 46, 356-370. [CrossRef]

37. Pollastri, S.; Tattini, M. Flavonols: Old Compounds for Old Roles. Ann. Bot. 2011, 108, 1225-1233. [CrossRef]

38. Fini, A.; Guidi, L.; Ferrini, F.; Brunetti, C.; Di Ferdinando, M.; Biricolti, S.; Pollastri, S.; Calamai, L.; Tattini, M. Drought Stress Has Contrasting Effects on Antioxidant Enzymes Activity and Phenylpropanoid Biosynthesis in Fraxinus ornus Leaves: An Excess Light Stress Affair? J. Plant Physiol. 2012, 169, 929-939. [CrossRef] [PubMed]

39. Caldwell, M.M.; Robberecht, R.; Flint, S.D. Internal Filters: Prospects for UV-Acclimation in Higher Plants. Physiol. Plant. 1983, 58, 445-450. [CrossRef]

40. Smith, G.J.; Markham, K.R. Tautomerism of Flavonol Glucosides: Relevance to Plant UV Protection and Flower Colour. J. Photochem. Photobiol. A Chem. 1998, 118, 99-105. [CrossRef]

41. Wang, T.; Li, Q.; Bi, K. Bioactive Flavonoids in Medicinal Plants: Structure, Activity and Biological Fate. Asian J. Pharm. Sci. 2018, 13, 12-23. [CrossRef] [PubMed] 
42. Narayana, K.R.; Reddy, M.S.; Chaluvadi, M.R.; Krishna, D.R. Bioflavonoids Classification, Pharmacological, Biochemical Effects and Therapeutic Potential. Indian J. Pharmacol. 2001, 33, 2-16.

43. Aherne, S.A.; O’Brien, N.M. Dietary Flavonols: Chemistry, Food Content, and Metabolism. Nutrition 2002, 18, 75-81. [CrossRef]

44. Heim, K.E.; Tagliaferro, A.R.; Bobilya, D.J. Flavonoid Antioxidants: Chemistry, Metabolism and Structure-Activity Relationships. J. Nutr. Biochem. 2002, 13, 572-584. [CrossRef]

45. Rice-evans, C.A.; Miller, N.J.; Bolwell, P.G.; Bramley, P.M.; Pridham, J.B. The Relative Antioxidant Activities of Plant-Derived Polyphenolic Flavonoids. Free Radic. Res. 1995, 22, 375-383. [CrossRef]

46. Rice-Evans, C.A.; Miller, N.J.; Paganga, G. Structure-Antioxidant Activity Relationships of Flavonoids and Phenolic Acids. Free Radic. Biol. Med. 1996, 20, 933-956. [CrossRef]

47. Soufi, O.; Romero, C.; Louaileche, H. Ortho-Diphenol Profile and Antioxidant Activity of Algerian Black Olive Cultivars: Effect of Dry Salting Process. Food Chem. 2014, 157, 504-510. [CrossRef]

48. Melidou, M.; Riganakos, K.; Galaris, D. Protection against Nuclear DNA Damage Offered by Flavonoids in Cells Exposed to Hydrogen Peroxide: The Role of Iron Chelation. Free Radic. Biol. Med. 2005, 39, 1591-1600. [CrossRef] [PubMed]

49. Le Roy, J.; Huss, B.; Creach, A.; Hawkins, S.; Neutelings, G. Glycosylation Is a Major Regulator of Phenylpropanoid Availability and Biological Activity in Plants. Front. Plant Sci. 2016, 7, 735. [CrossRef]

50. Shah, A.; Smith, D.L. Flavonoids in Agriculture: Chemistry and Roles in, Biotic and Abiotic Stress Responses, and Microbial Associations. Agronomy 2020, 10, 1209. [CrossRef]

51. Markham, K.R.; Porter, L.J. Flavonoids of the Primitive Liverwort Takakia and Their Taxonomic and Phylogenetic Significance. Phytochemistry 1979, 18, 611-615. [CrossRef]

52. Iwashina, T. The Structure and Distribution of the Flavonoids in Plants. J. Plant Res. 2000, 113, 287. [CrossRef]

53. Williamson, G.; Plumb, G.W.; Garcia-Conesa, M.T. Glycosylation, Esterification, and Polymerization of Flavonoids and Hydroxycinnamates: Effects on Antioxidant Properties. In Plant Polyphenols 2: Chemistry, Biology, Pharmacology, Ecology; Gross, G.G., Hemingway, R.W., Yoshida, T., Branham, S.J., Eds.; Springer: Boston, MA, USA, 1999; pp. 483-494.

54. Vogt, T.; Jones, P. Glycosyltransferases in Plant Natural Product Synthesis: Characterization of a Supergene Family. Trends Plant Sci. 2000, 5, 380-386. [CrossRef]

55. Gachon, C.M.M.; Langlois-Meurinne, M.; Saindrenan, P. Plant Secondary Metabolism Glycosyltransferases: The Emerging Functional Analysis. Trends Plant Sci. 2005, 10, 542-549. [CrossRef]

56. Brunetti, C.; Di Ferdinando, M.; Fini, A.; Pollastri, S.; Tattini, M. Flavonoids as Antioxidants and Developmental Regulators: Relative Significance in Plants and Humans. Int. J. Mol. Sci. 2013, 14, 3540-3555. [CrossRef] [PubMed]

57. Behr, M.; Neutelings, G.; El Jaziri, M.; Baucher, M. You Want It Sweeter: How Glycosylation Affects Plant Response to Oxidative Stress. Front. Plant Sci. 2020, 11, 1443. [CrossRef]

58. Cook, N.C.; Samman, S. Flavonoids-Chemistry, Metabolism, Cardioprotective Effects, and Dietary Sources. J. Nutr. Biochem. 1996, 7, 66-76. [CrossRef]

59. Swain, T.; Williams, C.A. The Role of Phenylalanine in Flavonoid Biosynthesis. Phytochemistry 1970, 9, 2115-2122. [CrossRef]

60. Widhalm, J.R.; Gutensohn, M.; Yoo, H.; Adebesin, F.; Qian, Y.; Guo, L.; Jaini, R.; Lynch, J.H.; McCoy, R.M.; Shreve, J.T.; et al. Identification of a Plastidial Phenylalanine Exporter That Influences Flux Distribution through the Phenylalanine Biosynthetic Network. Nat. Commun. 2015, 6, 8142. [CrossRef] [PubMed]

61. Qian, Y.; Lynch, J.H.; Guo, L.; Rhodes, D.; Morgan, J.A.; Dudareva, N. Completion of the Cytosolic Post-Chorismate Phenylalanine Biosynthetic Pathway in Plants. Nat. Commun. 2019, 10, 15. [CrossRef]

62. Petrussa, E.; Braidot, E.; Zancani, M.; Peresson, C.; Bertolini, A.; Patui, S.; Vianello, A. Plant Flavonoids—Biosynthesis, Transport and Involvement in Stress Responses. Int. J. Mol. Sci. 2013, 14, 14950-14973. [CrossRef]

63. Davies, K.M.; Schwinn, K.E.; Deroles, S.C.; Manson, D.G.; Lewis, D.H.; Bloor, S.J.; Bradley, J.M. Enhancing Anthocyanin Production by Altering Competition for Substrate between Flavonol Synthase and Dihydroflavonol 4-Reductase. Euphytica 2003, 131, 259-268. [CrossRef]

64. Owens, D.K.; Alerding, A.B.; Crosby, K.C.; Bandara, A.B.; Westwood, J.H.; Winkel, B.S.J. Functional Analysis of a Predicted Flavonol Synthase Gene Family in Arabidopsis. Plant Physiol. 2008, 147, 1046-1061. [CrossRef] [PubMed]

65. Quattrocchio, F.; Baudry, A.; Lepiniec, L.; Grotewold, E. The Regulation of Flavonoid Biosynthesis. In The Science of Flavonoids; Grotewold, E., Ed.; Springer: New York, NY, USA, 2006; pp. 97-122.

66. Abrahams, S.; Tanner, G.J.; Larkin, P.J.; Ashton, A.R. Identification and Biochemical Characterization of Mutants in the Proanthocyanidin Pathway in Arabidopsis. Plant Physiol. 2002, 130, 561-576. [CrossRef] [PubMed]

67. Pang, Y.; Wenger, J.P.; Saathoff, K.; Peel, G.J.; Wen, J.; Huhman, D.; Allen, S.N.; Tang, Y.; Cheng, X.; Tadege, M.; et al. A WD40 Repeat Protein from Medicago Truncatula Is Necessary for Tissue-Specific Anthocyanin and Proanthocyanidin Biosynthesis But Not for Trichome Development. Plant Physiol. 2009, 151, 1114-1129. [CrossRef] [PubMed]

68. Hichri, I.; Barrieu, F.; Bogs, J.; Kappel, C.; Delrot, S.; Lauvergeat, V. Recent Advances in the Transcriptional Regulation of the Flavonoid Biosynthetic Pathway. J. Exp. Bot. 2011, 62, 2465-2483. [CrossRef]

69. Xu, W.; Dubos, C.; Lepiniec, L. Transcriptional Control of Flavonoid Biosynthesis by MYB-BHLH-WDR Complexes. Trends Plant Sci. 2015, 20, 176-185. [CrossRef] [PubMed] 
70. Stracke, R.; Ishihara, H.; Huep, G.; Barsch, A.; Mehrtens, F.; Niehaus, K.; Weisshaar, B. Differential Regulation of Closely Related R2R3-MYB Transcription Factors Controls Flavonol Accumulation in Different Parts of the Arabidopsis thaliana Seedling. Plant J. 2007, 50, 660-677. [CrossRef]

71. Czemmel, S.; Stracke, R.; Weisshaar, B.; Cordon, N.; Harris, N.N.; Walker, A.R.; Robinson, S.P.; Bogs, J. The Grapevine R2R3-MYB Transcription Factor VvMYBF1 Regulates Flavonol Synthesis in Developing Grape Berries. Plant Physiol. 2009, 151, 1513-1530. [CrossRef] [PubMed]

72. Ravaglia, D.; Espley, R.V.; Henry-Kirk, R.A.; Andreotti, C.; Ziosi, V.; Hellens, R.P.; Costa, G.; Allan, A.C. Transcriptional Regulation of Flavonoid Biosynthesis in Nectarine (Prunus persica) by a Set of R2R3 MYB Transcription Factors. BMC Plant Biol. 2013, 13, 68. [CrossRef]

73. Tirumalai, V.; Swetha, C.; Nair, A.; Pandit, A.; Shivaprasad, P.V. MiR828 and MiR858 Regulate VvMYB114 to Promote Anthocyanin and Flavonol Accumulation in Grapes. J. Exp. Bot. 2019, 70, 4775-4792. [CrossRef]

74. Wagner, G.J.; Hrazdina, G. Endoplasmic Reticulum as a Site of Phenylpropanoid and Flavonoid Metabolism in Hippeastrum. Plant Physiol. 1984, 74, 901-906. [CrossRef]

75. Winkel-Shirley, B. Evidence for Enzyme Complexes in the Phenylpropanoid and Flavonoid Pathways. Physiol. Plant. 1999, 107, 142-149. [CrossRef]

76. Winkel, B.S.J. Metabolic Channeling in Plants. Annu. Rev. Plant Biol. 2004, 55, 85-107. [CrossRef]

77. Imlay, J.A.; Chin, S.M.; Linn, S. Toxic DNA Damage by Hydrogen Peroxide Through the Fenton Reaction In Vivo and In Vitro. Science 1988, 240, 640-642. [CrossRef]

78. Saslowsky, D.E.; Warek, U.; Winkel, B.S.J. Nuclear Localization of Flavonoid Enzymes in Arabidopsis. J. Biol. Chem. 2005, 280, 23735-23740. [CrossRef] [PubMed]

79. Zaprometov, M.N.; Nikolaeva, T.N. Chloroplasts Isolated from Kidney Bean Leaves Are Capable of Phenolic Compound Biosynthesis. Russ. J. Plant Physiol. 2003, 50, 623-626. [CrossRef]

80. Hernández, I.; Alegre, L.; Van Breusegem, F.; Munné-Bosch, S. How Relevant Are Flavonoids as Antioxidants in Plants? Trends Plant Sci. 2009, 14, 125-132. [CrossRef] [PubMed]

81. Debeaujon, I.; Peeters, A.J.M.; Léon-Kloosterziel, K.M.; Koornneef, M. The TRANSPARENT TESTA12 Gene of Arabidopsis Encodes a Multidrug Secondary Transporter-like Protein Required for Flavonoid Sequestration in Vacuoles of the Seed Coat Endothelium. Plant Cell 2001, 13, 853-871. [CrossRef]

82. Lepiniec, L.; Debeaujon, I.; Routaboul, J.-M.; Baudry, A.; Pourcel, L.; Nesi, N.; Caboche, M. Genetics and Biochemistry of Seed Flavonoids. Annu. Rev. Plant Biol. 2006, 57, 405-430. [CrossRef]

83. Yamasaki, H.; Sakihama, Y.; Ikehara, N. Flavonoid-Peroxidase Reaction as a Detoxification Mechanism of Plant Cells against $\mathrm{H}_{2} \mathrm{O}_{2}$. Plant Physiol. 1997, 115, 1405-1412. [CrossRef]

84. Ibrahim, R.K.; De Luca, V.; Khouri, H.; Latchinian, L.; Brisson, L.; Charest, P.M. Enzymology and Compartmentation of Polymethylated Flavonol Glucosides in Chrysosplenium americanum. Phytochemistry 1987, 26, 1237-1245. [CrossRef]

85. Heredia-Guerrero, J.A.; Benítez, J.J.; Domínguez, E.; Bayer, I.S.; Cingolani, R.; Athanassiou, A.; Heredia, A. Infrared Spectroscopy as a Tool to Study Plant Cuticles. Spectrosc. Eur. 2016, 28, 4.

86. Agati, G.; Brunetti, C.; Fini, A.; Gori, A.; Guidi, L.; Landi, M.; Sebastiani, F.; Tattini, M. Are Flavonoids Effective Antioxidants in Plants? Twenty Years of Our Investigation. Antioxidants 2020, 9, 1098. [CrossRef]

87. Herrmann, K. On the Occurrence of Flavonol and Flavone Glycosides in Vegetables. Z. Lebensm. Unters. 1988, 186, 1-5. [CrossRef]

88. Hutzler, P.; Fischbach, R.; Heller, W.; Jungblut, T.P.; Reuber, S.; Schmitz, R.; Veit, M.; Weissenböck, G.; Schnitzler, J.-P. Tissue Localization of Phenolic Compounds in Plants by Confocal Laser Scanning Microscopy. J. Exp. Bot. 1998, 49, 953-965. [CrossRef]

89. Zhao, J.; Dixon, R.A. The 'Ins' and 'Outs' of Flavonoid Transport. Trends Plant Sci. 2010, 15, 72-80. [CrossRef]

90. Zhao, J. Flavonoid Transport Mechanisms: How to Go, and with Whom. Trends Plant Sci. 2015, 20, 576-585. [CrossRef] [PubMed]

91. Marinova, K.; Pourcel, L.; Weder, B.; Schwarz, M.; Barron, D.; Routaboul, J.-M.; Debeaujon, I.; Klein, M. The Arabidopsis MATE Transporter TT12 Acts as a Vacuolar Flavonoid/H+-Antiporter Active in Proanthocyanidin-Accumulating Cells of the Seed Coat. Plant Cell 2007, 19, 2023-2038. [CrossRef]

92. Rea, P.A. Plant ATP-Binding Cassette Transporters. Annu. Rev. Plant Biol. 2007, 58, 347-375. [CrossRef]

93. Buer, C.S.; Muday, G.K.; Djordjevic, M.A. Flavonoids Are Differentially Taken up and Transported Long Distances in Arabidopsis. Plant Physiol. 2007, 145, 478-490. [CrossRef]

94. Shukla, P.R.; Skea, J.; Calvo Buendia, E.; Masson-Delmotte, V.; Pörtner, H.O.; Roberts, D.C.; Zhai, P.; Slade, R.; Connors, S.; Van Diemen, R. Climate Change and Land: An IPCC Special Report on Climate Change, Desertification, Land Degradation, Sustainable Land Management, Food Security, and Greenhouse Gas Fluxes in Terrestrial Ecosystems; IPCC: Geneva, Switzerland, 2019.

95. Caldwell, M.M.; Flint, S.D. Stratospheric Ozone Reduction, Solar UV-B Radiation and Terrestrial Ecosystems. Clim. Chang. 1994, 28, 375-394. [CrossRef]

96. Giorgi, F.; Lionello, P. Climate Change Projections for the Mediterranean Region. Glob. Planet. Chang. 2008, 63, 90-104. [CrossRef]

97. Lionello, P.; Abrantes, F.; Gacic, M.; Planton, S.; Trigo, R.; Ulbrich, U. The Climate of the Mediterranean Region: Research Progress and Climate Change Impacts. Reg. Environ. Chang. 2014, 14, 1679-1684. [CrossRef]

98. Lionello, P.; Scarascia, L. The Relation between Climate Change in the Mediterranean Region and Global Warming. Reg. Environ. Chang. 2018, 18, 1481-1493. [CrossRef] 
99. Daliakopoulos, I.N.; Tsanis, I.K.; Koutroulis, A.; Kourgialas, N.N.; Varouchakis, A.E.; Karatzas, G.P.; Ritsema, C.J. The Threat of Soil Salinity: A European Scale Review. Sci. Total Environ. 2016, 573, 727-739. [CrossRef] [PubMed]

100. Corwin, D.L. Climate Change Impacts on Soil Salinity in Agricultural Areas. Eur. J. Soil Sci. 2021, 72, 842-862. [CrossRef]

101. Davis, M.B. Range Shifts and Adaptive Responses to Quaternary Climate Change. Science 2001, 292, 673-679. [CrossRef] [PubMed]

102. Sardans, J.; Peñuelas, J. Plant-Soil Interactions in Mediterranean Forest and Shrublands: Impacts of Climatic Change. Plant Soil 2013, 365, 1-33. [CrossRef]

103. Matesanz, S.; Valladares, F. Ecological and Evolutionary Responses of Mediterranean Plants to Global Change. Environ. Exp. Bot. 2014, 103, 53-67. [CrossRef]

104. Sosa, T.; Alías, J.C.; Escudero, J.C.; Chaves, N. Interpopulational Variation in the Flavonoid Composition of Cistus ladanifer L. Exudate. Biochem. Syst. Ecol. 2005, 33, 353-364. [CrossRef]

105. Nakabayashi, R.; Yonekura-Sakakibara, K.; Urano, K.; Suzuki, M.; Yamada, Y.; Nishizawa, T.; Matsuda, F.; Kojima, M.; Sakakibara, H.; Shinozaki, K.; et al. Enhancement of Oxidative and Drought Tolerance in Arabidopsis by Overaccumulation of Antioxidant Flavonoids. Plant J. 2014, 77, 367-379. [CrossRef]

106. Popović, B.M.; Štajner, D.; Ždero-Pavlović, R.; Tumbas-Šaponjac, V.; Čanadanović-Brunet, J.; Orlović, S. Water Stress Induces Changes in Polyphenol Profile and Antioxidant Capacity in Poplar Plants (Populus spp.). Plant Physiol. Biochem. 2016, 105, 242-250. [CrossRef]

107. Nichols, S.N.; Hofmann, R.W.; Williams, W.M. Physiological Drought Resistance and Accumulation of Leaf Phenolics in White Clover Interspecific Hybrids. Environ. Exp. Bot. 2015, 119, 40-47. [CrossRef]

108. Fischbach, R.J.; Kossmann, B.; Panten, H.; Steinbrecher, R.; Heller, W.; Seidlitz, H.K.; Sandermann, H.; Hertkorn, N.; Schnitzler J.-P. Seasonal Accumulation of Ultraviolet-B Screening Pigments in Needles of Norway Spruce (Picea abies (L.) Karst.). Plant Cell Environ. 1999, 22, 27-37. [CrossRef]

109. Csepregi, K.; Coffey, A.; Cunningham, N.; Prinsen, E.; Hideg, É; Jansen, M.A.K. Developmental Age and UV-B Exposure Co-Determine Antioxidant Capacity and Flavonol Accumulation in Arabidopsis Leaves. Environ. Exp. Bot. 2017, 140, 19-25. [CrossRef]

110. Hectors, K.; Van Oevelen, S.; Geuns, J.; Guisez, Y.; Jansen, M.A.K.; Prinsen, E. Dynamic Changes in Plant Secondary Metabolites during UV Acclimation in Arabidopsis thaliana. Physiol. Plant. 2014, 152, 219-230. [CrossRef]

111. Sebastiani, F.; Torre, S.; Gori, A.; Brunetti, C.; Centritto, M.; Ferrini, F.; Tattini, M. Dissecting Adaptation Mechanisms to Contrasting Solar Irradiance in the Mediterranean Shrub Cistus Incanus. Int. J. Mol. Sci. 2019, 20, 3599. [CrossRef] [PubMed]

112. Brossa, R.; Casals, I.; Pintó-Marijuan, M.; Fleck, I. Leaf Flavonoid Content in Quercus ilex L. Resprouts and Its Seasonal Variation. Trees 2009, 23, 401-408. [CrossRef]

113. Zandalinas, S.I.; Sales, C.; Beltrán, J.; Gómez-Cadenas, A.; Arbona, V. Activation of Secondary Metabolism in Citrus Plants Is Associated to Sensitivity to Combined Drought and High Temperatures. Front. Plant Sci. 2017, 7, 1954. [CrossRef]

114. Martinez, V.; Mestre, T.C.; Rubio, F.; Girones-Vilaplana, A.; Moreno, D.A.; Mittler, R.; Rivero, R.M. Accumulation of Flavonols over Hydroxycinnamic Acids Favors Oxidative Damage Protection under Abiotic Stress. Front. Plant Sci. 2016, 7, 838. [CrossRef]

115. Agati, G.; Biricolti, S.; Guidi, L.; Ferrini, F.; Fini, A.; Tattini, M. The Biosynthesis of Flavonoids Is Enhanced Similarly by UV Radiation and Root Zone Salinity in L. vulgare Leaves. J. Plant Physiol. 2011, 168, 204-212. [CrossRef]

116. Jorge, T.F.; Tohge, T.; Wendenburg, R.; Ramalho, J.C.; Lidon, F.C.; Ribeiro-Barros, A.I.; Fernie, A.R.; António, C. Salt-Stress Secondary Metabolite Signatures Involved in the Ability of Casuarina Glauca to Mitigate Oxidative Stress. Environ. Exp. Bot. 2019, 166, 103808. [CrossRef]

117. Xu, Z.; Zhou, J.; Ren, T.; Du, H.; Liu, H.; Li, Y.; Zhang, C. Salt Stress Decreases Seedling Growth and Development but Increases Quercetin and Kaempferol Content in Apocynum venetum. Plant Biol. 2020, 22, 813-821. [CrossRef] [PubMed]

118. Sánchez-Rodríguez, E.; Moreno, D.A.; Ferreres, F.; Rubio-Wilhelmi, M.D.M.; Ruiz, J.M. Differential Responses of Five Cherry Tomato Varieties to Water Stress: Changes on Phenolic Metabolites and Related Enzymes. Phytochemistry 2011, 72, 723-729. [CrossRef] [PubMed]

119. Nakabayashi, R.; Mori, T.; Saito, K. Alternation of Flavonoid Accumulation under Drought Stress in Arabidopsis thaliana. Plant Signal. Behav. 2014, 9, e29518. [CrossRef] [PubMed]

120. Griesser, M.; Weingart, G.; Schoedl-Hummel, K.; Neumann, N.; Becker, M.; Varmuza, K.; Liebner, F.; Schuhmacher, R.; Forneck, A. Severe Drought Stress Is Affecting Selected Primary Metabolites, Polyphenols, and Volatile Metabolites in Grapevine Leaves (Vitis vinifera cv. Pinot Noir). Plant Physiol. Biochem. 2015, 88, 17-26. [CrossRef]

121. Hodaei, M.; Rahimmalek, M.; Arzani, A.; Talebi, M. The Effect of Water Stress on Phytochemical Accumulation, Bioactive Compounds and Expression of Key Genes Involved in Flavonoid Biosynthesis in Chrysanthemum morifolium L. Ind. Crop. Prod. 2018, 120, 295-304. [CrossRef]

122. Liu, M.; Li, X.; Liu, Y.; Cao, B. Regulation of Flavanone 3-Hydroxylase Gene Involved in the Flavonoid Biosynthesis Pathway in Response to UV-B Radiation and Drought Stress in the Desert Plant, Reaumuria soongorica. Plant Physiol. Biochem. 2013, 73, 161-167. [CrossRef]

123. Gharibi, S.; Sayed Tabatabaei, B.E.; Saeidi, G.; Talebi, M.; Matkowski, A. The Effect of Drought Stress on Polyphenolic Compounds and Expression of Flavonoid Biosynthesis Related Genes in Achillea pachycephala Rech.f. Phytochemistry 2019, 162, 90-98. [CrossRef] 
124. Baldoni, E.; Genga, A.; Cominelli, E. Plant MYB Transcription Factors: Their Role in Drought Response Mechanisms. Int. J. Mol. Sci. 2015, 16, 15811-15851. [CrossRef]

125. Wang, F.; Zhu, H.; Chen, D.; Li, Z.; Peng, R.; Yao, Q. A Grape BHLH Transcription Factor Gene, VvbHLH1, Increases the Accumulation of Flavonoids and Enhances Salt and Drought Tolerance in Transgenic Arab. thaliana. Plant Cell Tiss. Organ Cult. 2016, 125, 387-398. [CrossRef]

126. De Simón, B.F.; Sanz, M.; Cervera, M.T.; Pinto, E.; Aranda, I.; Cadahía, E. Leaf Metabolic Response to Water Deficit in Pinus Pinaster Ait. Relies upon Ontogeny and Genotype. Environ. Exp. Bot. 2017, 140, 41-55. [CrossRef]

127. Mittler, R. Abiotic Stress, the Field Environment and Stress Combination. Trends Plant Sci. 2006, 11, 15-19. [CrossRef]

128. Ahuja, I.; de Vos, R.C.H.; Bones, A.M.; Hall, R.D. Plant Molecular Stress Responses Face Climate Change. Trends Plant Sci. 2010, 15, 664-674. [CrossRef]

129. Hasanuzzaman, M.; Nahar, K.; Alam, M.M.; Roychowdhury, R.; Fujita, M. Physiological, Biochemical, and Molecular Mechanisms of Heat Stress Tolerance in Plants. Int. J. Mol. Sci. 2013, 14, 9643-9684. [CrossRef]

130. Lin-Wang, K.; Micheletti, D.; Palmer, J.; Volz, R.; Lozano, L.; Espley, R.; Hellens, R.P.; Chagnè, D.; Rowan, D.D.; Troggio, M.; et al. High Temperature Reduces Apple Fruit Colour via Modulation of the Anthocyanin Regulatory Complex. Plant Cell Environ. 2011, 34, 1176-1190. [CrossRef] [PubMed]

131. Movahed, N.; Pastore, C.; Cellini, A.; Allegro, G.; Valentini, G.; Zenoni, S.; Cavallini, E.; D’Incà, E.; Tornielli, G.B.; Filippetti, I. The Grapevine VviPrx31 Peroxidase as a Candidate Gene Involved in Anthocyanin Degradation in Ripening Berries under High Temperature. J. Plant Res. 2016, 129, 513-526. [CrossRef] [PubMed]

132. Pastore, C.; Dal Santo, S.; Zenoni, S.; Movahed, N.; Allegro, G.; Valentini, G.; Filippetti, I.; Tornielli, G.B. Whole Plant Temperature Manipulation Affects Flavonoid Metabolism and the Transcriptome of Grapevine Berries. Front. Plant Sci. 2017, 8, 929. [CrossRef] [PubMed]

133. Zhang, Y.; Virjamo, V.; Du, W.; Yin, Y.; Nissinen, K.; Nybakken, L.; Guo, H.; Julkunen-Tiitto, R. Effects of Soil Pyrene Contamination on Growth and Phenolics in Norway Spruce (Picea abies) Are Modified by Elevated Temperature and $\mathrm{CO}_{2}$. Env. Sci. Pollut. Res. 2018, 25, 12788-12799. [CrossRef] [PubMed]

134. Nissinen, K.; Nybakken, L.; Virjamo, V.; Julkunen-Tiitto, R. Slow-Growing Salix Repens (Salicaceae) Benefits from Changing Climate. Environ. Exp. Bot. 2016, 128, 59-68. [CrossRef]

135. Nissinen, K.; Virjamo, V.; Randriamanana, T.; Sobuj, N.; Sivadasan, U.; Mehtätalo, L.; Beuker, E.; Julkunen-Tiitto, R.; Nybakken, L. Responses of Growth and Leaf Phenolics in European Aspen (Populus tremula) to Climate Change during Juvenile Phase Change. Can. J. For. Res. 2017, 47, 1350-1363. [CrossRef]

136. Kellomäki, S.; Wang, K.-Y. Growth and Resource Use of Birch Seedlings Under Elevated Carbon Dioxide and Temperature. Ann. Bot. 2001, 87, 669-682. [CrossRef]

137. Lo Gullo, M.A.; Salleo, S. Different Strategies of Drought Resistance in Three Mediterranean Sclerophyllous Trees Growing in the Same Environmental Conditions. New Phytol. 1988, 108, 267-276. [CrossRef] [PubMed]

138. Vogt, T.; Proksch, P.; Gülz, P.-G. Epicuticular Flavonoid Aglycones in the Genus Cistus, Cistaceae. J. Plant Physiol. 1987, 131, 25-36. [CrossRef]

139. Chaves, N.; Escudero, J.C.; Gutiérrez-Merino, C. Seasonal Variation of Exudate of Cistus ladanifer. J. Chem. Ecol. 1993, 19, 2577-2591. [CrossRef] [PubMed]

140. Chaves, N.; Escudero, J.C.; Gutiérrez-Merino, C. Role of Ecological Variables in the Seasonal Variation of Flavonoid Content of Cistus ladanifer Exudate. J. Chem. Ecol. 1997, 23, 579-603. [CrossRef]

141. Moreira, X.; Abdala-Roberts, L.; Hidalgo-Galvez, M.D.; Vázquez-González, C.; Pérez-Ramos, I.M. Micro-Climatic Effects on Plant Phenolics at the Community Level in a Mediterranean Savanna. Sci. Rep. 2020, 10, 14757. [CrossRef] [PubMed]

142. Bornman, J.F.; Barnes, P.W.; Robson, T.M.; Robinson, S.A.; Jansen, M.A.K.; Ballaré, C.L.; Flint, S.D. Linkages between Stratospheric Ozone, UV Radiation and Climate Change and Their Implications for Terrestrial Ecosystems. Photochem. Photobiol. Sci. 2019, 18, 681-716. [CrossRef]

143. Stapleton, A. Ultraviolet Radiation and Plants: Burning Questions. Plant Cell 1992, 4, 1353-1358. [CrossRef] [PubMed]

144. Gerhardt, K.E.; Lampi, M.A.; Greenberg, B.M. The Effects of Far-red Light on Plant Growth and Flavonoid Accumulation in Brassica Napus in the Presence of Ultraviolet B Radiation. Photochem. Photobiol. 2008, 84, 1445-1454. [CrossRef]

145. Agati, G.; Brunetti, C.; Di Ferdinando, M.; Ferrini, F.; Pollastri, S.; Tattini, M. Functional Roles of Flavonoids in Photoprotection: New Evidence, Lessons from the Past. Plant Physiol. Biochem. 2013, 72, 35-45. [CrossRef]

146. Ryan, K.G.; Markham, K.R.; Bloor, S.J.; Bradley, J.M.; Mitchell, K.A.; Jordan, B.R. UVB Radiation Induced Increase in Quercetin: Kaempferol Ratio in Wild-Type and Transgenic Lines of Petunia. Photochem. Photobiol. 1998, 68, 323-330. [CrossRef]

147. Ryan, K.G.; Swinny, E.E.; Markham, K.R.; Winefield, C. Flavonoid Gene Expression and UV Photoprotection in Transgenic and Mutant Petunia Leaves. Phytochemistry 2002, 59, 23-32. [CrossRef]

148. Kotilainen, T.; Tegelberg, R.; Julkunen-Tiitto, R.; Lindfors, A.; Aphalo, P.J. Metabolite Specific Effects of Solar UV-A and UV-B on Alder and Birch Leaf Phenolics. Glob. Change Biol. 2008, 14, 1294-1304. [CrossRef]

149. Osmond, C.B.; Foyer, C.H.; Bock, G.; Grace, S.C.; Logan, B.A. Energy Dissipation and Radical Scavenging by the Plant Phenylpropanoid Pathway. Philos. Trans. R. Soc. London. Ser. B Biol. Sci. 2000, 355, 1499-1510. [CrossRef] 
150. Hectors, K.; van Oevelen, S.; Guisez, Y.; Prinsen, E.; Jansen, M.A. The Phytohormone Auxin Is a Component of the Regulatory System That Controls UV-mediated Accumulation of Flavonoids and UV-induced Morphogenesis. Physiol. Plant. 2012, 145, 594-603. [CrossRef]

151. Parihar, P.; Singh, S.; Singh, R.; Singh, V.P.; Prasad, S.M. Effect of Salinity Stress on Plants and Its Tolerance Strategies: A Review. Env. Sci. Pollut. Res. 2015, 22, 4056-4075. [CrossRef]

152. Libutti, A.; Cammerino, A.R.B.; Monteleone, M. Risk Assessment of Soil Salinization Due to Tomato Cultivation in Mediterranean Climate Conditions. Water 2018, 10, 1503. [CrossRef]

153. Grattan, S.R.; Grieve, C.M. Mineral Nutrient Acquisition and Response by Plants Grown in Saline Environments. Handb. Plant Crop Stress 1999, 2, 203-229.

154. Fageria, N.K.; Gheyi, H.R.; Moreira, A. Nutrient Bioavailability in Salt Affected Soils. J. Plant Nutr. 2011, 34, 945-962. [CrossRef]

155. Romero-Aranda, R.; Soria, T.; Cuartero, J. Tomato Plant-Water Uptake and Plant-Water Relationships under Saline Growth Conditions. Plant Sci. 2001, 160, 265-272. [CrossRef]

156. Wang, X.; Wang, W.; Huang, J.; Peng, S.; Xiong, D. Diffusional Conductance to $\mathrm{CO}_{2}$ Is the Key Limitation to Photosynthesis in Salt-stressed Leaves of Rice (Oryza sativa). Physiol. Plant. 2018, 163, 45-58. [CrossRef]

157. Miller, G.; Suzuki, N.; Ciftci-Yilmaz, S.; Mittler, R. Reactive Oxygen Species Homeostasis and Signalling during Drought and Salinity Stresses. Plant Cell Environ. 2010, 33, 453-467. [CrossRef]

158. Sairam, R.K.; Tyagi, A. Physiology and Molecular Biology of Salinity Stress Tolerance in Plants. Curr. Sci. 2004, 86, 407-421.

159. Ben Abdallah, S.; Aung, B.; Amyot, L.; Lalin, I.; Lachâal, M.; Karray-Bouraoui, N.; Hannoufa, A. Salt Stress (NaCl) Affects Plant Growth and Branch Pathways of Carotenoid and Flavonoid Biosyntheses in Solanum nigrum. Acta Physiol. Plant. $2016,38,72$. [CrossRef]

160. Mrázová, A.; Belay, S.A.; Eliášová, A.; Perez-Delgado, C.; Kaducová, M.; Betti, M.; Vega, J.M.; Pal'ove-Balang, P. Expression, Activity of Phenylalanine-Ammonia-Lyase and Accumulation of Phenolic Compounds in Lotus japonicus under Salt Stress. Biologia 2017, 72, 36-42. [CrossRef]

161. Li, X.; Kim, Y.B.; Kim, Y.; Zhao, S.; Kim, H.H.; Chung, E.; Lee, J.-H.; Park, S.U. Differential Stress-Response Expression of Two Flavonol Synthase Genes and Accumulation of Flavonols in Tartary Buckwheat. J. Plant Physiol. 2013, 170, 1630-1636. [CrossRef] [PubMed]

162. Tattini, M.; Traversi, M.L.; Castelli, S.; Biricolti, S.; Guidi, L.; Massai, R.; Tattini, M.; Traversi, M.L.; Castelli, S.; Biricolti, S.; et al. Contrasting Response Mechanisms to Root-Zone Salinity in Three Co-Occurring Mediterranean Woody Evergreens: A Physiological and Biochemical Study. Funct. Plant Biol. 2009, 36, 551-563. [CrossRef] [PubMed]

163. Mittler, R. Oxidative Stress, Antioxidants and Stress Tolerance. Trends Plant Sci. 2002, 7, 405-410. [CrossRef]

164. Das, K.; Roychoudhury, A. Reactive Oxygen Species (ROS) and Response of Antioxidants as ROS-Scavengers during Environmental Stress in Plants. Front. Environ. Sci. 2014, 2, 53. [CrossRef]

165. Cruz de Carvalho, M.H. Drought Stress and Reactive Oxygen Species. Plant Signal. Behav. 2008, 3, 156-165. [CrossRef]

166. Krieger-Liszkay, A.; Fufezan, C.; Trebst, A. Singlet Oxygen Production in Photosystem II and Related Protection Mechanism. Photosynth. Res. 2008, 98, 551-564. [CrossRef]

167. Symonowicz, M.; Kolanek, M. Flavonoids and Their Properties to Form Chelate Complexes. Biotechnol. Food Sci. 2012.

168. Dias, M.C.; Pinto, D.C.G.A.; Silva, A.M.S. Plant Flavonoids: Chemical Characteristics and Biological Activity. Molecules 2021, 26, 5377. [CrossRef]

169. Jogawat, A. Crosstalk Among Phytohormone Signaling Pathways During Abiotic Stress. In Molecular Plant Abiotic Stress; John Wiley \& Sons Ltd.: Hoboken, NJ, USA, 2019; pp. 209-220.

170. Ullah, A.; Manghwar, H.; Shaban, M.; Khan, A.H.; Akbar, A.; Ali, U.; Ali, E.; Fahad, S. Phytohormones Enhanced Drought Tolerance in Plants: A Coping Strategy. Environ. Sci Pollut. Res. 2018, 25, 33103-33118. [CrossRef] [PubMed]

171. Zhao, Y. Auxin Biosynthesis and Its Role in Plant Development. Annu. Rev. Plant Biol. 2010, 61, 49-64. [CrossRef]

172. Jacobs, M.; Rubery, P.H. Naturally Occurring Auxin Transport Regulators. Science 1988, 241, 346-349. [CrossRef] [PubMed]

173. Brown, D.E.; Rashotte, A.M.; Murphy, A.S.; Normanly, J.; Tague, B.W.; Peer, W.A.; Taiz, L.; Muday, G.K. Flavonoids Act as Negative Regulators of Auxin Transport In Vivo in Arabidopsis. Plant Physiol. 2001, 126, 524-535. [CrossRef] [PubMed]

174. Buer, C.S.; Muday, G.K. The Transparent Testa4 Mutation Prevents Flavonoid Synthesis and Alters Auxin Transport and the Response of Arabidopsis Roots to Gravity and Light. Plant Cell 2004, 16, 1191-1205. [CrossRef]

175. Kuhn, B.M.; Geisler, M.; Bigler, L.; Ringli, C. Flavonols Accumulate Asymmetrically and Affect Auxin Transport in Arabidopsis. Plant Physiol. 2011, 156, 585-595. [CrossRef]

176. Yin, R.; Han, K.; Heller, W.; Albert, A.; Dobrev, P.I.; Zažímalová, E.; Schäffner, A.R. Kaempferol 3-O-Rhamnoside-7-O-Rhamnoside Is an Endogenous Flavonol Inhibitor of Polar Auxin Transport in Arabidopsis Shoots. New Phytol. 2014, 201, 466-475. [CrossRef]

177. Teale, W.D.; Pasternak, T.; Dal Bosco, C.; Dovzhenko, A.; Kratzat, K.; Bildl, W.; Schwörer, M.; Falk, T.; Ruperti, B.; V Schaefer, J. Flavonol-mediated Stabilization of PIN Efflux Complexes Regulates Polar Auxin Transport. EMBO J. 2021, 40, e104416. [CrossRef]

178. Fernández-Marcos, M.; Sanz, L.; Lewis, D.R.; Muday, G.K.; Lorenzo, O. Control of Auxin Transport by Reactive Oxygen and Nitrogen Species. In Polar Auxin Transport; Chen, R., Baluška, F., Eds.; Springer: Berlin/Heidelberg, Germany, 2013; pp. 103-117.

179. Lewis, D.R.; Ramirez, M.V.; Miller, N.D.; Vallabhaneni, P.; Ray, W.K.; Helm, R.F.; Winkel, B.S.J.; Muday, G.K. Auxin and Ethylene Induce Flavonol Accumulation through Distinct Transcriptional Networks. Plant Physiol. 2011, 156, 144-164. [CrossRef] [PubMed] 
180. Grunewald, W.; Smet, I.D.; Lewis, D.R.; Löfke, C.; Jansen, L.; Goeminne, G.; Bossche, R.V.; Karimi, M.; Rybel, B.D.; Vanholme, B.; et al. Transcription Factor WRKY23 Assists Auxin Distribution Patterns during Arabidopsis Root Development through Local Control on Flavonol Biosynthesis. Proc. Natl. Acad. Sci. USA 2012, 109, 1554-1559. [CrossRef]

181. Shi, H.; Chen, L.; Ye, T.; Liu, X.; Ding, K.; Chan, Z. Modulation of Auxin Content in Arabidopsis Confers Improved Drought Stress Resistance. Plant Physiol. Biochem. 2014, 82, 209-217. [CrossRef] [PubMed]

182. Jansen, M.A.K. Ultraviolet-B Radiation Effects on Plants: Induction of Morphogenic Responses. Physiol. Plant. 2002, 116, 423-429. [CrossRef]

183. Xu, W.; Jia, L.; Shi, W.; Liang, J.; Zhou, F.; Li, Q.; Zhang, J. Abscisic Acid Accumulation Modulates Auxin Transport in the Root Tip to Enhance Proton Secretion for Maintaining Root Growth under Moderate Water Stress. New Phytol. 2013, 197, 139-150. [CrossRef]

184. Tuteja, N. Abscisic Acid and Abiotic Stress Signaling. Plant Signal. Behav. 2007, 2, 135-138. [CrossRef]

185. Sah, S.K.; Reddy, K.R.; Li, J. Abscisic Acid and Abiotic Stress Tolerance in Crop Plants. Front. Plant Sci. 2016, 7, 571. [CrossRef] [PubMed]

186. Brunetti, C.; Sebastiani, F.; Tattini, M. Review: ABA, Flavonols, and the Evolvability of Land Plants. Plant Sci. 2019, 280, 448-454. [CrossRef]

187. Heine, G.F.; Hernandez, J.M.; Grotewold, E. Two Cysteines in Plant R2R3 MYB Domains Participate in REDOX-Dependent DNA Binding. J. Biol. Chem. 2004, 279, 37878-37885. [CrossRef] [PubMed]

188. Watkins, J.M.; Chapman, J.M.; Muday, G.K. Abscisic Acid-Induced Reactive Oxygen Species Are Modulated by Flavonols to Control Stomata Aperture. Plant Physiol. 2017, 175, 1807-1825. [CrossRef]

189. Mittler, R.; Blumwald, E. The Roles of ROS and ABA in Systemic Acquired Acclimation. Plant Cell 2015, 27, 64-70. [CrossRef] [PubMed]

190. Wang, P.; Song, C.-P. Guard-Cell Signalling for Hydrogen Peroxide and Abscisic Acid. New Phytol. 2008, 178, 703-718. [CrossRef] [PubMed] 